University of Nebraska - Lincoln

DigitalCommons@University of Nebraska - Lincoln

$12-2001$

\title{
Comparison of Instream Methods for Measuring Hydraulic Conductivity in Sandy Streambeds
}

\author{
Matthew K. Landon \\ U.S. Geological Survey \\ David L. Rus \\ U.S. Geological Survey \\ F. Edwin Harvey \\ University of Nebraska - Lincoln, feharvey1@unl.edu
}

Follow this and additional works at: https://digitalcommons.unl.edu/natrespapers

Part of the Natural Resources and Conservation Commons

Landon, Matthew K.; Rus, David L.; and Harvey, F. Edwin, "Comparison of Instream Methods for Measuring Hydraulic Conductivity in Sandy Streambeds" (2001). Papers in Natural Resources. 154.

https://digitalcommons.unl.edu/natrespapers/154

This Article is brought to you for free and open access by the Natural Resources, School of at DigitalCommons@University of Nebraska - Lincoln. It has been accepted for inclusion in Papers in Natural Resources by an authorized administrator of DigitalCommons@University of Nebraska - Lincoln. 


\title{
Comparison of Instream Methods for Measuring Hydraulic Conductivity in Sandy Streambeds
}

\author{
by Matthew K. Landon ${ }^{1,3}$, David L. Rus ${ }^{1}$, and F. Edwin Harvey ${ }^{2}$
}

\begin{abstract}
Streambed hydraulic conductivity $(K)$ values were determined at seven stream transects in the Platte River Basin in Nebraska using different instream measurement techniques. Values were compared to determine the most appropriate technique(s) for use in sandy streambeds. Values of $\mathrm{K}$ determined from field falling- and constant-head permeameter tests analyzed using the Darcy equation decreased as permeameter diameter increased. Seepage meters coupled with hydraulic gradient measurements failed to yield $\mathrm{K}$ values in $40 \%$ of the trials. Consequently, Darcy permeameter and seepage meter tests were not preferred approaches. In the upper $0.25 \mathrm{~m}$ of the streambed, field falling- and constant-head permeameter tests analyzed with the Hvorslev solution generally had similar $\mathrm{K}$ values that were significantly greater than those determined using the Hazen grain-size, Bouwer and Rice slug test for anisotropic and isotropic conditions, and Alyamani and Sen grain-size methods; median differences between these tests and the Hvorslev falling-head $60 \mathrm{~cm}$ diameter permeameter were about $8,9,17$, and $35 \mathrm{~m} / \mathrm{day}$, respectively. The Hvorslev falling-head permeameter test is considered the most robust method for measuring $\mathrm{K}$ of the upper $0.25 \mathrm{~m}$ of the streambed because of the inherent limitations of the empirical grain-size methods and less sediment disturbance for permeameter than slug tests. However, lateral variability in $K$ along transects on the Platte, North Platte, and Wood Rivers was greater than variability in $K$ between valid permeameter, grain-size, or slug tests, indicating that the method used may matter less than making enough measurements to characterize spatial variability adequately. At the Platte River tributary sites, the upper $0.3 \mathrm{~m}$ of the streambed typically had greater $\mathrm{K}$ than sediment located 0.3 to $2.5 \mathrm{~m}$ below the streambed surface, indicating that deposits below the streambed may limit ground water/surface water fluxes. The Hvorslev permeameter tests are not a practical measurement approach for these greater depths. Thus, selection of a method for measuring streambed $\mathrm{K}$ needs to consider the vertical location of the sediments that are most likely to limit the rate of ground water/surface water interaction.
\end{abstract}

\section{Introduction}

Streambed hydraulic conductivity $(\mathrm{K})$ is an important parameter to estimate in order to quantify the magnitude and spatial distribution of ground water/surface water interactions. Because silt, clay, and organic materials often are deposited in streams, the streambed can have lower $\mathrm{K}$ than the aquifer, thereby restricting ground water/surface water fluxes (Rosenshein 1988; Larkin and Sharp 1992; Conrad and Beljin 1996). Such restriction can occur even in predominantly sandy streambeds if $\mathrm{K}$ is lower than that of the surrounding aquifer. Determination of streambed $\mathrm{K}$ can be important for studies designed to determine base flow (Petersen et al. 1995; Cey et al. 1998); to quantify the impacts of pumping wells on streamflow (Sophocleous et al. 1995; Chen and Yin 1999; Hunt 1999); to simulate regional ground water flow balances (McDonald and Harbaugh 1988; Luckey and Becker 1999; Yu and Schwartz 1999); and to quantify solute transport, retention, and exchange between ground water and surface water (Harvey and Bencala 1993; McMahon et al. 1995; Hart et al. 1999).

Streambed $\mathrm{K}$ has been estimated using a variety of approaches including numerical modeling (Yager 1993; Sophocleous et al.

'U.S. Geological Survey, 100 Centennial Mall N., Room 406 Federal Building, Lincoln, NE 68508; (402) 437-5836; fax (402) 437-5139

${ }^{2}$ School of Natural Resource Sciences and Conservation and Survey Division, Institute of Agriculture and Natural Resources, University of Nebraska-Lincoln, 113 Nebraska Hall, Lincoln, NE 68588-0157

${ }^{3}$ Corresponding author: landon@usgs.gov

Received January 2001, accepted June 2001.
1995) and analytical solutions for pumping-aquifer tests conducted near streams (Hantush 1965; Hunt 1999), analytical solutions for analysis of bank storage effects (Barlow and Moench 1998; Zlotnik and Huang 1999), chemical tracer experiments (Harvey and Bencala 1993; Hart et al. 1999), and physical instream methods. For regional studies, it is often beyond the resources of investigations to install monitoring wells, conduct pumping-aquifer tests, and evaluate streambed properties using analytical or numerical modeling or to conduct laborious and expensive chemical tracer tests considering the number of stream reaches that need to be characterized. In contrast, physical instream methods are relatively quick and inexpensive and measurements can be made at many locations using portable equipment. Consequently, a comparative study of instream methods was performed as a pilot investigation to guide subsequent efforts to generate streambed $\mathrm{K}$ data for input into regional groundwater-flow models of the Platte River in Nebraska (COHYST 2000 ) being developed to quantify river gains and losses from interaction with ground water (Figure 1).

Instream methods of determining $\mathrm{K}$ include slug tests (Lee and Cherry 1978; Duwelius 1996; Cey et al. 1998; Springer et al. 1999), in situ permeameter tests (McMahon et al. 1995; Duwelius 1996; Lindgren and Landon 2000; Rosenberry 2000), and seepage flux measurements with seepage meters coupled with measurement of hydraulic gradient through the streambed (Lee and Cherry 1978; Wolf et al. 1991b). In addition, streambed samples can be collected for grain-size analysis and $\mathrm{K}$ can be estimated from grainsize distribution (Vukovic and Soro 1992). Although field permeameter and coupled seepage meter/hydraulic gradient measurements measure vertical $\mathrm{K}\left(\mathrm{K}_{\mathrm{v}}\right)$, slug tests measure horizontal $\mathrm{K}\left(\mathrm{K}_{\mathrm{h}}\right)$, and 


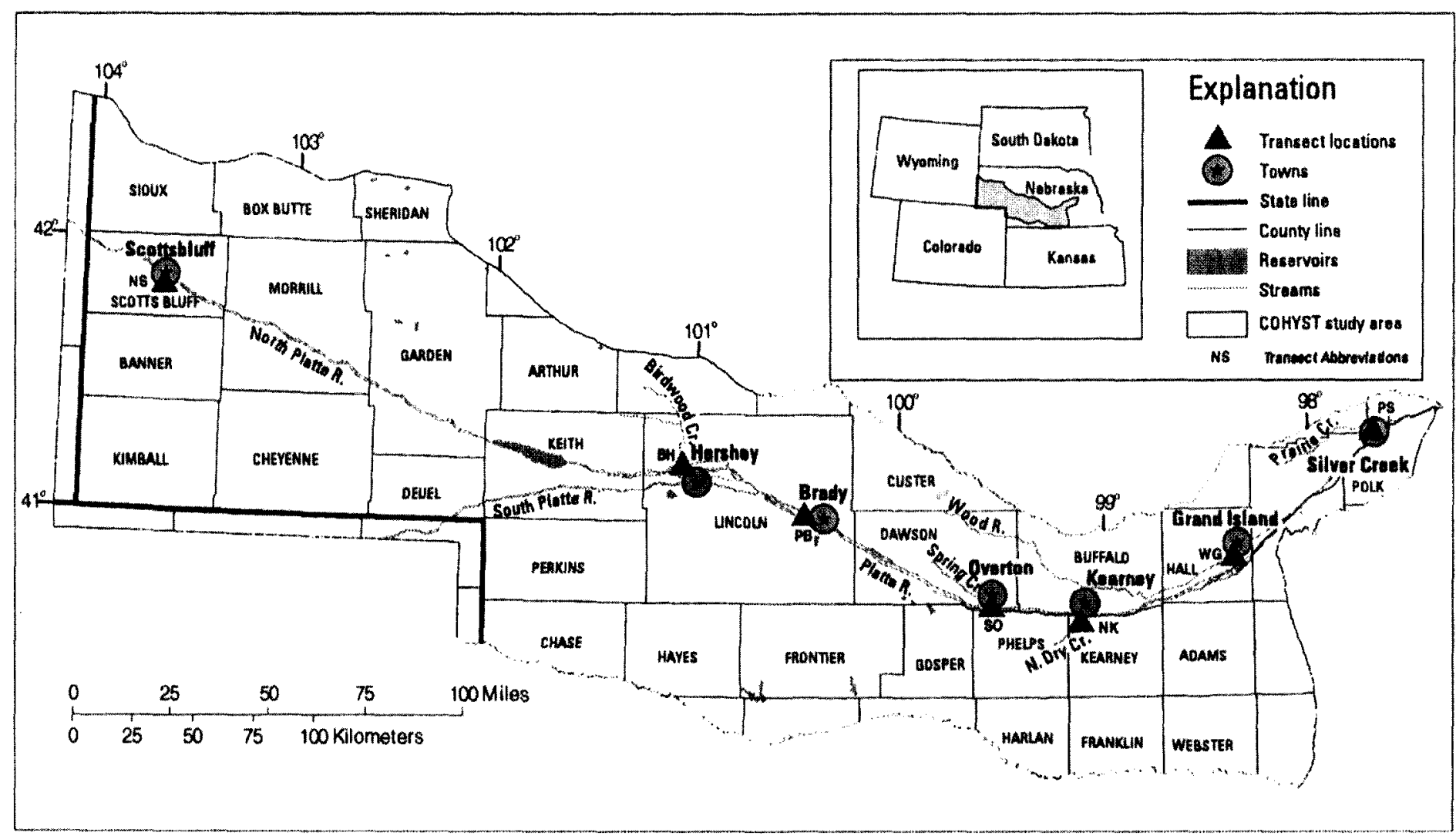

Figure 1. Map showing location of study area and transects at which streambed hydraulic conductivity was measured.

Table 1

Site Characteristics

\begin{tabular}{|c|c|c|c|c|c|c|c|c|c|}
\hline Site Name & $\begin{array}{l}\text { Site } \\
\text { Code }\end{array}$ & $\begin{array}{l}\text { Channel } \\
\text { Width } \\
\text { (m) }\end{array}$ & $\begin{array}{l}\text { Max. } \\
\text { Depth }^{1} \\
(\mathrm{~m})\end{array}$ & $\begin{array}{l}\text { Min. } \\
\text { Depth }^{1} \\
\text { (m) }\end{array}$ & $\begin{array}{c}\text { Stream } \\
\text { Flow } \\
\left(\mathrm{m}^{3} / \mathrm{sec}\right)\end{array}$ & $\begin{array}{c}\text { Mean } \\
\text { Velocity } \\
(\mathrm{m} / \mathrm{sec})\end{array}$ & $\begin{array}{l}\text { Stream } \\
\text { Slope }^{2} \\
(\mathrm{~m} / \mathrm{km})\end{array}$ & $\begin{array}{c}\text { Median } \\
\text { Grain-Size } \\
\text { (mm) }\end{array}$ & Bed Description \\
\hline \multicolumn{10}{|l|}{ Main-Stem Sites } \\
\hline $\begin{array}{l}\text { North Platte River } \\
\text { at Scottsbluff, Nebraska }\end{array}$ & NS & 60.5 & 0.79 & 0.11 & 12.5 & 0.56 & 1.17 & 1.21 & $\begin{array}{l}\text { Coarse to very coarse sand with } \\
\text { some sand and gravel }\end{array}$ \\
\hline $\begin{array}{l}\text { Platte River near } \\
\text { Brady, Nebraska }\end{array}$ & PB & 144 & 3.61 & .20 & 4.526 .3 & ${ }^{5.6} .62$ & 1.27 & 1.20 & Sand and gravel \\
\hline \multicolumn{10}{|l|}{ Wood River Site } \\
\hline $\begin{array}{l}\text { Wood River near } \\
\text { Grand Island, Nebraska }\end{array}$ & WG & 8.8 & .66 & .20 & 1.7 & .59 & 1.14 & .87 & $\begin{array}{l}\text { Medium to coarse sand overlying } \\
\text { fine and medium sand }\end{array}$ \\
\hline \multicolumn{10}{|l|}{ Tributary Sites } \\
\hline $\begin{array}{l}\text { Birdwood Creek } \\
\text { near Hershey, Nebraska }\end{array}$ & $\mathrm{BH}$ & 25.3 & .56 & .12 & 43.9 & 6.69 & 1.23 & .33 & Fine sand \\
\hline $\begin{array}{l}\text { Spring Creek near } \\
\text { Overton, Nebraska }\end{array}$ & SO & 8.5 & .35 & .08 & .50 & .38 & 1.35 & .59 & $\begin{array}{l}\text { Sand and gravel overlying fine } \\
\text { sand and silt }\end{array}$ \\
\hline $\begin{array}{l}\text { North Dry Creek } \\
\text { near Kearney, Nebraska }\end{array}$ & NK & 10.4 & .44 & .05 & ${ }^{4} .15$ & .27 & 1.08 & .49 & $\begin{array}{l}\text { Fine sand with coarse sand } \\
\text { overlying fine sand and silt }\end{array}$ \\
\hline $\begin{array}{l}\text { Praire Creek near } \\
\text { Silver Creek, Nebraska }\end{array}$ & PS & 10.7 & .21 & .04 & 3.24 & .24 & .81 & .42 & Fine sand \\
\hline \multicolumn{10}{|c|}{$\begin{array}{l}\text { 'Determined from surveying across streambed transect unless otherwise noted. } \\
\text { "Taken from Bentall (1991) and from U.S. Geological Survey topographic guadrangle maps, 7.5-minute series. } \\
\text { "Based on water depths recorded for slug tests at the measuring points. } \\
\text { "Mean streamflow for a day of the test period based on stream-gauge records of the United States Geological Survey and the Nebraska Department of Water Resources (NDWR). } \\
\text { "Based on NDWR gatige on the North Chamel Platte River approximately } 8 \mathrm{~km} \text { below the study site. } \\
\text { "Based on discharge measurement notes from the gatuge at a similar discharge. }\end{array}$} \\
\hline
\end{tabular}

$\mathrm{K}$ values from grain-size methods are nondirectional (isotropic), these different $\mathrm{K}$ values are directly compared in this study for the purpose of characterizing streambed $\mathrm{K}$ values. Commonly used sim- ulation models such as MODFLOW (McDonald and Harbaugh 1988) treat ground water/surface water fluxes through a streambed as being vertical. In reality, both horizontal and vertical fluxes can 
occur and the directions are a complex function of many hydrogeologic variables (Harvey and Bencala 1993; Woessner 2000). Particularly in broad, braided streams like the Platte River that partially penetrate a relatively permeable alluvial aquifer and may have many flow-through or parallel-flow reaches (Woessner 2000), ground water/surface water fluxes are expected to have both horizontal and vertical components and the distribution of these directional fluxes will be highly complex. In addition, the anisotropy ratio $\left(\mathrm{K}_{\mathrm{h}} / \mathrm{K}_{\mathrm{v}}\right)$ is expected to be small for relatively small-scale $\mathrm{K}$ tests (Freeze and Cherry 1979; Butler 1998) considering that the streambed sediments of the Platte River and tributaries are generally sandy and well rounded (Kircher 1983; Kinzel et al. 1999).

This study was conducted because well-constrained values of streambed $\mathrm{K}$ are critical for estimating ground water/surface water fluxes, and the performance of instream methods for determining $\mathrm{K}$ in sandy streambed environments has not been evaluated. Previous studies have indicated that substantial differences between slug tests and grain size can occur in sandy aquifers (Wolf et al. 1991a; Millham and Howes 1995). However, field permeameters and coupled seepage meter/hydraulic gradient measurements can be used only to determine $\mathrm{K}$ at or near the sediment surface. While the instream methods listed have been used in lake studies (Lee and Cherry 1978; Wolf et al. 1991b), we are unaware of a study that has compared K values determined with these different methods in lakes. Moreover, sandy streambed environments will have greater water velocity and sediment mobility than typical lake environments, which could affect the performance of some of the methods. For example, it was expected that the Platte River and its tributaries would have flow velocities (Table 1) greater than environments in which seepage meters are used-typically less than $0.2 \mathrm{~m} / \mathrm{sec}$ (Lee and Cherry 1978). Moreover, the bedload deposition and scour that occurs in active sandy stream channels has the potential to bury or unearth, respectively, devices such as seepage meters and field permeameters that are placed into the streambed to measure streambed $\mathrm{K}$.

All techniques of determining $\mathrm{K}$ have uncertainties. The magnitude of the uncertainty is highly dependent upon the conditions under which the tests are conducted (Butler 1998). To isolate the effect of method imprecision from other sources of variability in $\mathrm{K}$ values, duplicate tests were performed for all methods at each location and the differences between duplicates were analyzed statistically. Differences in $\mathrm{K}$ values determined using different methods are often interpreted to result from differences in measurement scale (Wolf et al. 1991a; Millham and Howes 1995; Rovey and Cherkauer 1995), although the relationship between measurement scale and $\mathrm{K}$ has been questioned in some studies (Butler and Healy 1998). Over a range of scales, it has been documented that spatial variations in $\mathrm{K}$ can range over several orders of magnitude (Freeze and Cherry 1979; Eggleston and Rojstaczer 1998). This variability is a major source of uncertainty in measured $\mathrm{K}$ values and in comparing values determined using different methods. Because all instream measurements disturb the streambed, tests using different methods cannot be conducted at exactly the same location on the streambed. Thus, spatial uncertainty in $\mathrm{K}$ values has the potential to have a substantial effect on the results of comparative studies of field methods for determining $\mathrm{K}$. To address the expected problem of spatial variability in $\mathrm{K}$ on the results, many measurements were made and the results of side-by-side tests using the same methods and different methods were analyzed statistically to evaluate the significance of differences in values due to different methods and local scale spatial variability.
This study compares streambed $\mathbf{K}$ determined using different instream measurement techniques, including field falling- and constant-head permeameter tests of different sizes analyzed using Hvorslev (1951) and Darcy solutions, seepage meters of different sizes coupled with hydraulic gradient measurements, slug tests, and grain-size data used in two empirical formulas. The purpose of the study is to determine which technique(s) are most appropriate for measuring $\mathrm{K}$ in sandy streambeds considering the reproducibility and sensitivity to design of each technique, differences between techniques, and spatial variability. Statistical tests are applied to evaluate the importance of these factors to variability in $\mathrm{K}$ values.

\section{Description of Study Area}

Most of the flow in the North Platte, South Platte, and Platte Rivers (collectively hereafter referred to as the main-stem rivers) is derived from spring snowmelt in the Rocky Mountains in Colorado and Wyoming (Eschner et al. 1983), whereas flow in the tributaries of the main-stem rivers is derived from local precipitation and ground water discharge. Precipitation on the Great Plains ranges from 330 to $650 \mathrm{~mm}$ annually in the study area. Streams in the study area are hydraulically connected to ground water in Pleistocene alluvial deposits and the Tertiary Ogallala Formation and White River Group of the High Plains aquifer. The main-stem rivers are predominantly braided and the bed material generally comprises sand and gravel with local deposits of silt- and clay-sized particles in low energy environments. The tributaries generally have well-defined channels and sandy bed materials with some siltand clay-sized particles.

\section{Methods}

\section{Design of Data Collection}

Determinations of $\mathrm{K}$ were made along transects across streams at seven locations from August through October 1999 (Figure 1). Measurements were made at one site on the North Platte River at Scottsbluff (NS), one site on the main stem of the Platte River near Brady (PB), and five tributary sites including Wood River near Grand Island (WG), Birdwood Creek near Hershey (BH), Spring Creek near Overton (SO), North Dry Creek near Kearney (NK), and Prairie Creek near Silver Creek (PS) (Table 1). Although the WG site was on the tributary Wood River, a north channel of the Platte River used to join the Wood River about $7.1 \mathrm{~km}$ above the measurement location before being cut off several years ago (Woodward 2000). Because this lower reach of the Wood River once was impacted by water and sediment transport in the Platte River, the WG site has different sediments than other Platte River tributaries. For the purposes of discussing the results at similar sites, the sites were classified into main stem (NS and $\mathrm{PB}$ ), Wood River (WG), and tributary (BH, SO, NK, and PS) sites.

At the NS and PB transects, measurements were made with each method at four clusters. At the much narrower tributaries (Table 1), measurements were made at two clusters along transects. At the WG site, measurements were made along two transects, each with two clusters. The clusters were about equally spaced across the stream at all transects.

Because all of the methods disturb the streambed, equipment for the different testing methods could not be placed in exactly the same location. Instead, the equipment for the different tests was placed into the streambed along lines perpendicular to the transect but in close proximity to each other. 


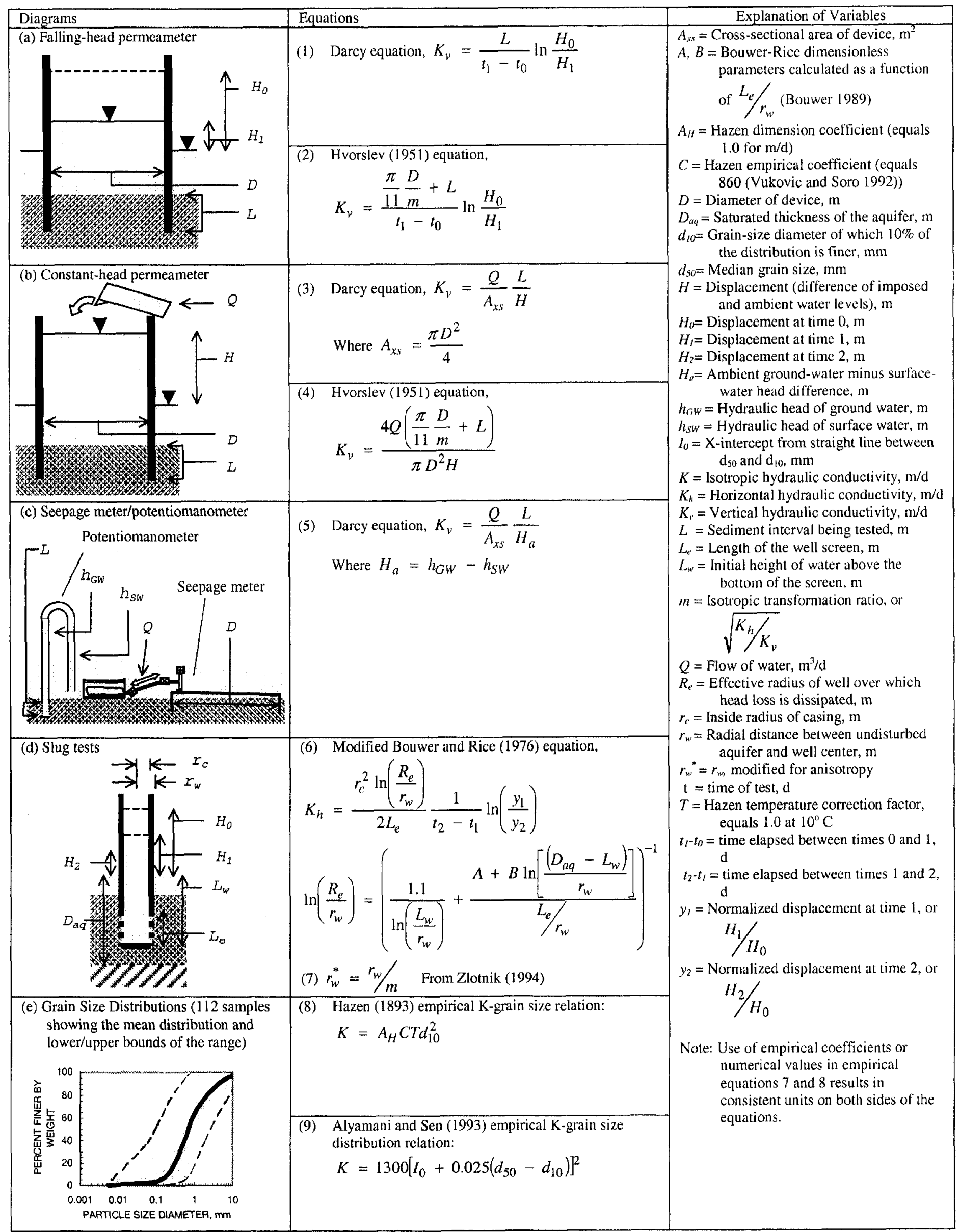

Figure 2. Diagrams of instrument design, equations, and explanation of variables for instream methods used to determine streambed hydraulic conductivity for (a) falling-head permeameters, (b) constant-head permeameters, (c) seepage meter/potentiomanometers, (d) slug tests, and (e) empirical grain-size methods. 
permeameter (Hvorslev 1951, p. 31, case 6) for falling-head tests (Figure 2a, Equation 2) and constant-head tests (Figure 2b, Equation 4). The Hvorslev equations required the isotropic transformation ratio ( $\mathrm{m}$; Equations 2 and 4 ) be estimated. For a sandy streambed with rounded particles, isotropic conditions were assumed for the upper $0.3 \mathrm{~m}$.

Average $\mathrm{K}_{v}$ for each cluster was calculated using duplicate measurements made at each station with the $60 \mathrm{~cm}$ falling-head permeameters. These average $\mathrm{K}_{\mathrm{v}}$ values and the distances between clusters were used to calculate a width-weighted average $K_{v}$ for each transect for this method.

\section{Seepage Meter/Hydraulic Gradient Measurements}

Each seepage meter consisted of a covered cylinder about $0.2 \mathrm{~m}$ long connected to a sheltered bag (Figure 2c). The $28 \mathrm{~cm}$ device was made of schedule 80 PVC covered on one end with sheet metal (sealed with silicone caulk) and beveled on the outside of the open end. The $61 \mathrm{~cm}$ device was made of a $208 \mathrm{~L}$ steel drum cut in half. The $91 \mathrm{~cm}$ device was made of a circular livestock-watering tank. The measurement bags were gusseted, had a maximum volume of $4.4 \mathrm{~L}$, and were made of $1 \mathrm{~mm}$ thick polyethylene. Bag type has not been found to affect the results of seepage meter tests significantly (Erickson 1981; Isiorho and Meyer 1999). The bags were connected to the seepage meters with $1.1 \mathrm{~cm}$ inside diameter (I.D.) reinforced plastic tubing and a valve system for controlling the measurement period. Fellows and Brezonik (1980) found that seepage-meter-flow resistance was negligible for connector tube diameters greater than about $0.5 \mathrm{~cm}$ and seepage meter flow rates of less than about $50 \mathrm{~cm}^{3} / \mathrm{min}$. The relatively low seepage meter flow rates (maximum of $20.4 \mathrm{~cm}^{3} / \mathrm{min}$ ) and the larger diameter tubing used in this study indicate that resistance caused by the tubing was negligible.

To reduce the effect of stream velocity on the measurement bag, a shelter for the bag was constructed that consisted of a semicircular piece of Schedule-80 PVC with sheet metal attached to the bottom and ends. Holes were drilled in the shelter to allow pressure equilibration with the stream. One end-piece was removed for inserting the bag and had an access hole to allow tubing attached to the bag to exit the shelter.

During installation, the covered cylinders were placed at a slight angle to the streambed to allow venting of air bubbles out of the meter prior to measurement. The cylinders generally were pushed into the streambed about 0.17 to $0.19 \mathrm{~m}$. A measured volume of water $(0.5$ to $1.0 \mathrm{~L})$ was added to the measurement bags so that downward seepage fluxes, should they occur, could be measured and because use of dry bags has been shown to reduce inflow in response to deformation and relaxation of the submerged bags (Erickson 1981; Shaw and Prepas 1990; Belanger and Montgomery 1992). Once installed, the cylinders sat for 10 to 15 minutes before any tests were conducted. It was expected that this was a sufficient time for the predominantly sandy sediments to equilibrate following meter installation.

The seepage flux was measured as the change in volume in the measurement bag after two to four hours. Two seepage measurements were conducted in each device at each location. At several times during the seepage measurements, the ambient hydraulic gradient between the ground water and surface water was recorded using a hydraulic potentiomanometer after the design of Winter et al. (1988) (Figure 2c). The average hydraulic gradient during the seepage measurements was calculated using the data from the potentiomanometer. The Darcy equation (Figure 2c, Equation 5) was used to calculate $K_{v}$.

\section{Slug Tests}

Shallow wells with $2.5 \mathrm{~cm}$ outside diameter (O.D). and a $1.3 \mathrm{~cm}$ I.D. alloy-steel casing were driven into the streambed. The screen had $2.5 \mathrm{~cm}$ O.D. and $1.9 \mathrm{~cm}$ I.D. with fifteen $5.1 \mathrm{~cm}$ long by $0.5 \mathrm{~mm}$ wide vertical slots over a $47 \mathrm{~cm}$ interval. Slug tests were conducted at three depths at each station with the screen at depth intervals of about 0.07 to $0.54,0.98$ to 1.45 , and 1.90 to $2.37 \mathrm{~m}$ below the streambed. About 3.8 to 8.3 casing volumes of water were withdrawn to develop the well.

Pneumatic slug tests were conducted by attaching a gas-tight manifold to the top of the casing and applying a vacuum to draw the water level into a clear piece of PVC pipe in the manifold, so that the initial displacement could be measured. The vacuum then was released and the response was recorded using a Druck ${ }^{\circledR}$ PDCR 35/D 10-pounds-per-square-inch submersible pressure transducer attached to a Campbell ${ }^{\circledR}$ CR 10 data logger. At least two replicate tests with the same displacement were done at each screen depth.

Slug tests with similar displacements to those used in the field were performed in a large water-filled tank. These tests indicated that the time for the water level to recover to the initial level was substantially shorter (about one second) than for any of the field tests, indicating that sediments limited the rate of water flow out of the well during the field tests, not the well casing and screen.

Slug-test results were analyzed using the method of Bouwer and Rice (1976) and Bouwer (1989) (Figure 2d, Equation 6) to calculate horizontal $\mathrm{K}\left(\mathrm{K}_{\mathrm{h}}\right)$. The Bouwer and Rice (1976) method assumes isotropic conditions, but an extension of the Bouwer and Rice method by Zlotnik (1994) that considers the effect of anisotropic sediments on the calculated $K_{h}$ also was used. Using this method, the anisotropy ratio $\left(\mathrm{K}_{\mathrm{h}} / \mathrm{K}_{\mathrm{v}}\right)$ is determined externally or assumed and inserted into Equation 7 (Figure 2d, subsequently $r_{w}{ }^{*}$ is substituted for $r_{w}$ in Equation 6). Based on typical $K_{h} / K_{v}$ values of 1 to 10 for relatively small-scale tests (Freeze and Cherry 1979; Butler 1998), a $K_{h} / K_{v}$ of 10 was assumed for all slug-test $K_{h}$ values corrected for anisotropy to bound the expected effects of anisotropy on $\mathrm{K}_{\mathrm{h}}$ values.

\section{Grain-Size Analyses}

Shallow streambed samples were collected from the upper $0.2 \mathrm{~m}$ using a BMH-53 piston-style sampler (Edwards and Glysson 1988). At the NS and WG sites, deeper core samples were collected to depths of about $2.5 \mathrm{~m}$ using a $122 \mathrm{~cm}$ long $3.8 \mathrm{~cm}$ I.D. pistoncore barrel. In the saturated sands sampled, core recoveries were about $50 \%$ to $60 \%$, so lithologic records were incomplete. Loss of equipment prevented collection of cores to $2.5 \mathrm{~m}$ at the $\mathrm{PB}, \mathrm{BH}, \mathrm{SO}$, $\mathrm{PS}$, and NK sites. At these sites, cores to about $0.6 \mathrm{~m}$ were collected using hand-driven $3.8 \mathrm{~cm}$ I.D. polycarbonate tubes. Core samples were subsampled by lithologic layer and depth interval.

Grain-size distributions (Figure 2e) were determined by sieve analysis at the University of Nebraska-Lincoln Soils Laboratory. Field samples were split into two fractions in the laboratory and both subsamples were analyzed for making comparisons of the reproducibility of grain-size distributions.

Values of $\mathrm{K}$ (isotropic) were estimated from the diameter at which $10 \%$ of the grain-size distribution is finer $\left(\mathrm{d}_{10}\right)$ using the widely applied, empirical formula of Hazen (1893; Figure 2e, Equation 8). The Hazen formula includes a temperature correction 
(equal to 1.0 at a temperature of $10^{\circ} \mathrm{C}$, the approximate mean annual air temperature along the Platte River in Nebraska), an empirical coefficient (for sand, a value of 860 was used; Vukovic and Soro 1992, p. 12), and a dimension coefficient ( 1.0 for $\mathrm{K}$ values in $\mathrm{m} /$ day). Values of $\mathrm{K}$ also were estimated using the method of Alyamani and Sen (1993), which incorporates the slope and intercept of the grain-size distribution curve between $d_{10}$ and $d_{50}$ (Figure 2e, Equation 9), rather than relying on a single representative grain-size parameter, such as the $\mathrm{d}_{10}$ used in the Hazen method.

Cores of the upper $0.2 \mathrm{~m}$ sometimes were split into multiple samples that were analyzed for grain-size distribution. In these cases, the harmonic mean K (Freeze and Cherry 1979, p. 34) for the upper $0.2 \mathrm{~m}$ was calculated from the $\mathrm{K}$ values of individual samples in that interval to obtain $\mathrm{K}$ values that were comparable directly to those determined for the permeameters and seepage meters.

\section{Statistical Analyses}

Sign tests (Helsel and Hirsch 1992) were used to determine if differences in $\mathrm{K}$ between paired duplicate tests, side-by-side tests, and different methods were statistically significant. The entire set of paired data for each comparison was analyzed. For example, for a comparison of $\mathrm{K}$ values determined using the Hazen (GSH) and Alyamani and Sen (GSA) grain-size methods, the GSH K value was paired with the GSA K value at the same station, and the entire data set, consisting of paired values from each individual station, was analyzed to determine if there were significant differences between the GSH and GSA K values. The sign test is fully nonparametric (no assumptions about the distribution of the differences between the groups are required) and determines if one group tends to produce different values from the other group. If the attained significance level ( $p$-value) was less than a predetermined significance level ( $\alpha$ $=0.05$ ), the differences in $\mathrm{K}$ between paired groups were considered significant. The median difference between paired data sets is the most robust estimator of the magnitude of the differences between data sets (Helsel and Hirsch 1992) and was computed for all comparisons. All statistics were determined using S-Plus 2000 software, professional release version 1 (Mathsoft 1999).

\section{Results and Discussion}

\section{Sources of Variability and Comparison of Hydraulic Conductivity Values}

Variations in $\mathrm{K}$ could be caused by (1) imprecision and size dependence of each measurement method, (2) spatial variability in sediment characteristics, and (3) differences between measurement methods. The results of measurements designed to identify variations in $\mathrm{K}$ related to each of these factors are presented in the following sections.

\section{Reproducibility and Size Dependence of Measurements}

Measurement precision was a minor-to-negligible source of variation in $\mathrm{K}$. For 17 of the $23 \mathrm{~K}$ calculation methods evaluated, there were no significant differences between duplicate tests. Significant differences between duplicate tests occurred for the CHP14D, CHP28D, CHP14H, CHP28H, GSH, and GSA (abbreviations defined in Table 2) methods (Table 3), although the median differences of each of these methods were less than $2 \mathrm{~m} /$ day. These differences between duplicate tests are a small imprecision relative to the general range of $\mathrm{K}$ values measured at the sites of 20 to 200
Table 3

Differences in Hydraulic Conductivity Values Determined for Duplicate Tests and Side-by-Side Tests for Each Method Evaluated

\begin{tabular}{|c|c|c|c|c|c|c|}
\hline \multirow[b]{2}{*}{ Method } & \multicolumn{3}{|c|}{ Comparison of Duplicate Tests } & \multicolumn{3}{|c|}{ Comparison of Side-by-Side Tests } \\
\hline & $\begin{array}{c}\text { Number } \\
\text { of } \\
\text { Tests }\end{array}$ & $\begin{array}{c}\text { Attained } \\
\text { Significance } \\
\text { (p-value) }\end{array}$ & $\begin{array}{c}\text { Median } \\
\text { Difference } \\
\text { (m/day) }\end{array}$ & $\begin{array}{c}\text { Number } \\
\text { of } \\
\text { Tests }\end{array}$ & $\begin{array}{c}\text { Attained } \\
\text { Significance } \\
\text { (p-value) }\end{array}$ & $\begin{array}{c}\text { Median } \\
\text { Difference } \\
(\mathbf{m} / \text { day })\end{array}$ \\
\hline CHP14D & 37 & 0.01 & 1.3 & 34 & 0,12 & 2.8 \\
\hline CHP28D & 38 & 0.01 & 1.4 & 36 & 0.62 & -2.4 \\
\hline CHPGOD & 37 & 1.00 & -0.1 & 34 & 1.00 & 0.0 \\
\hline CHP9OD & 38 & 0.87 & 0.2 & 36 & 0.87 & -3.9 \\
\hline CHP14H & 38 & 0.01 & 1.3 & 36 & 0.24 & 2.0 \\
\hline CHP28H & 38 & 0.01 & 1.8 & 36 & 1.00 & -1.8 \\
\hline $\mathrm{CHP} 60 \mathrm{H}$ & 37 & 1.00 & 0.0 & 35 & 1.00 & 0.8 \\
\hline СНР9OH & 38 & 0.87 & 0.4 & 36 & 0.87 & -5.5 \\
\hline FHPI4D & 38 & 0.42 & 0.9 & 36 & 0.07 & 2.6 \\
\hline FHP28D & 38 & 0.42 & 0.3 & 36 & 0.87 & 1.8 \\
\hline FHP60D & 38 & 0.26 & 0.4 & 36 & 0.62 & 0.3 \\
\hline FHP90D & 38 & 0.32 & -0.3 & 36 & 0.24 & 1.2 \\
\hline FHPI4H & 38 & 0.26 & I.I & 36 & 0.03 & 2.0 \\
\hline FHP28H & 38 & 0.42 & 0.5 & 36 & 0.62 & 2.4 \\
\hline FHP60H & 38 & 0.26 & 0.9 & 36 & 0.62 & 2.9 \\
\hline FHP90H & 37 & 0.19 & -1.2 & 36 & 0.62 & 2.7 \\
\hline SEM28 & 14 & 0.79 & 1.3 & 11 & 1.00 & 0.4 \\
\hline SEM6I & 12 & 0.15 & 0.3 & 12 & 0.77 & 0.3 \\
\hline SEM9 1 & 8 & 1.00 & 0.0 & 6 & 1.00 & 0.4 \\
\hline GSH & 112 & 0.00 & 0.9 & 34 & 0.39 & 2.0 \\
\hline GSA & 112 & 0.00 & 0.8 & 34 & 0.23 & -2.0 \\
\hline SLUGI & 41 & 0.53 & 0.0 & 14 & 1.00 & 0.0 \\
\hline SLUGA & 44 & 0.17 & -0.2 & 14 & 1.00 & 0.2 \\
\hline
\end{tabular}

$\mathrm{m} /$ day considering typical uncertainties in $\mathrm{K}$ of an order of magnitude or more due to heterogeneity and scale (Freeze and Cherry 1979; Eggleston and Rojstaczer 1998). Sources of measurement imprecision for each technique are discussed next.

\section{Field Permeameters}

The differences between duplicate tests for the 14 and $28 \mathrm{~cm}$ constant-head permeameters reflect primarily the sensitivity of these tests to the height of displacement. However, even for those constant-head tests that showed significant dependence on displacement, median differences between duplicate tests at different displacements were less than $4 \mathrm{~m} /$ day. Thus, the practical importance of the dependence of the constant-head test results on displacement may be minimal.

For falling-head tests, there were similar differences in displacement between duplicate tests for different sizes of permeameter, and reproducible results were obtained for all sizes. The effects of different displacements are likely to be less for the falling-head than the constant-head tests because the displacement adjusts dynamically throughout a falling-head test rather than being fixed as in the constant-head test.

Factors that could contribute to measurement uncertainty associated with field permeameter tests include (1) scouring of sediment around permeameters, (2) development of micro-erosional preferential pathways resulting from excessive head gradients (Sillanpäa 1956), (3) disturbance of soil structure (Fadl 1979), and (4) boundary flow or side leakage at the sediment permeameter interface (Fadl 1979; Hill and King 1982). These factors generally did not result in significant differences between duplicate tests. 

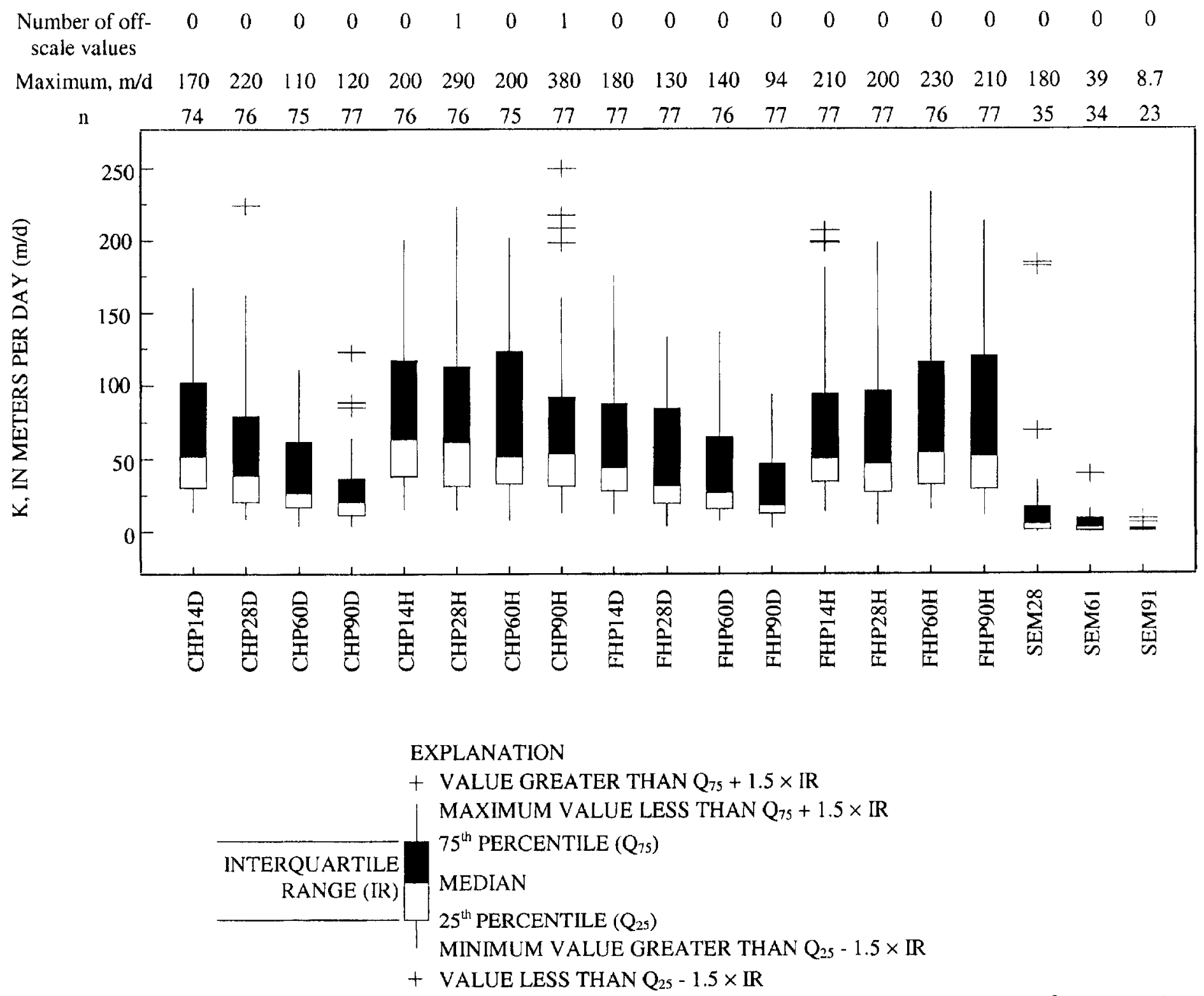

Figure 3. Box plots showing hydraulic conductivity values determined using different diameters of field permeameters and seepage meters. The number of hydraulic conductivity values determined ( $n$ ) using each method also is shown. Method abbreviations are defined in Table 2.

Significant differences were detected between all diameters of the field permeameter tests (both constant- and falling-head) when analyzed with the Darcy equation (Figure 3, Table 4). In contrast, most of the field permeameter tests of different diameters analyzed with the Hvorslev equations were not significantly different. The exception to this observation was for the $28 \mathrm{~cm}$ permeameters, which had significantly different $K_{v}$ values (when analyzed with the Hvorslev equation) from other diameters for five of the six comparisons (Table 4). The reasons for the anomalous results obtained with the $28 \mathrm{~cm}$ permeameters could not be determined.

Values of $\mathrm{K}_{\mathrm{v}}$ decreased as diameter increased for field permeameter tests analyzed using the Darcy equation. Because the same tests did not show this size dependence when analyzed with the Hvorslev equations, the results indicate that there are errors associated with the use of the Darcy equation to analyze the field permeameter tests. This result is not unexpected given that the application of the Darcy equation to the field permeameter problem assumes that all head loss occurs across the sediment inside the permeameter and disregards radial head loss from the bottom of the permeameter. For an equal displacement, flow out of the meter (Figure 2a) increases as diameter increases, and this increase in flow causes more radial head loss. Thus, the assumptions of the Darcy equation deviate further from reality for the field permeameter test as diameter and displacement increase. These limitations to applying the Darcy solution to field permeameter tests were known in advance, but because this method has been used for measuring $\mathrm{K}_{\mathrm{v}}$ in shallow saturated sands, it was used for comparison with more sophisticated approaches. It is likely that $\mathrm{K}_{\mathrm{v}}$ calculated with the Hvorslev equation for different sizes of permeameters were not significantly different because this method considers both head losses inside the permeameter and radial head losses outside the permeameter through the incorporation of a shape factor (Hvorslev 1951).

\section{Seepage Meter/Hydraulic Gradient Measurements}

Values of $\mathrm{K}_{v}$ determined with all three sizes of seepage meters coupled with hydraulic gradient measurements were not significantly different where duplicate $K_{v}$ values were determined. However, when considering those cases in which $\mathrm{K}_{\mathrm{v}}$ values could not be determined from one or both duplicate measurements, this approach was not reproducible for estimating $K_{v}$. The SEM28, SEM61, and 
Number of

$\begin{array}{cllllllllll}\begin{array}{c}\text { off-scale } \\ \text { values }\end{array} & 0 & 0 & 1 & 0 & 0 & 0 & 0 & 0 & 0 & 0\end{array}$

Maximum 200200380210230210290200240160

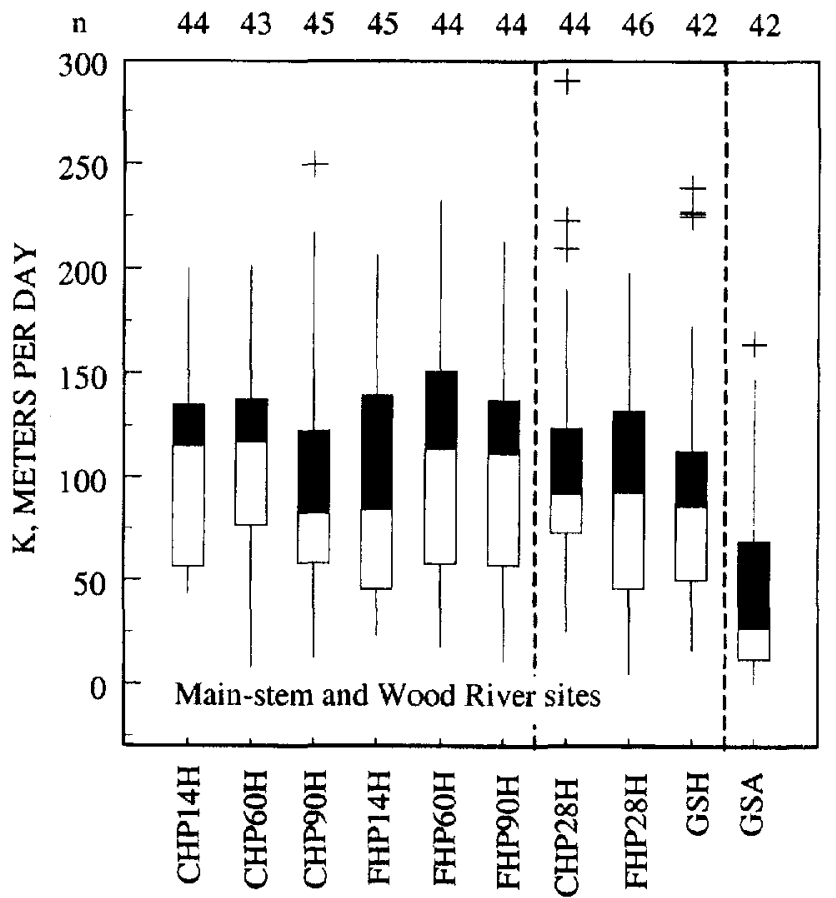

b.

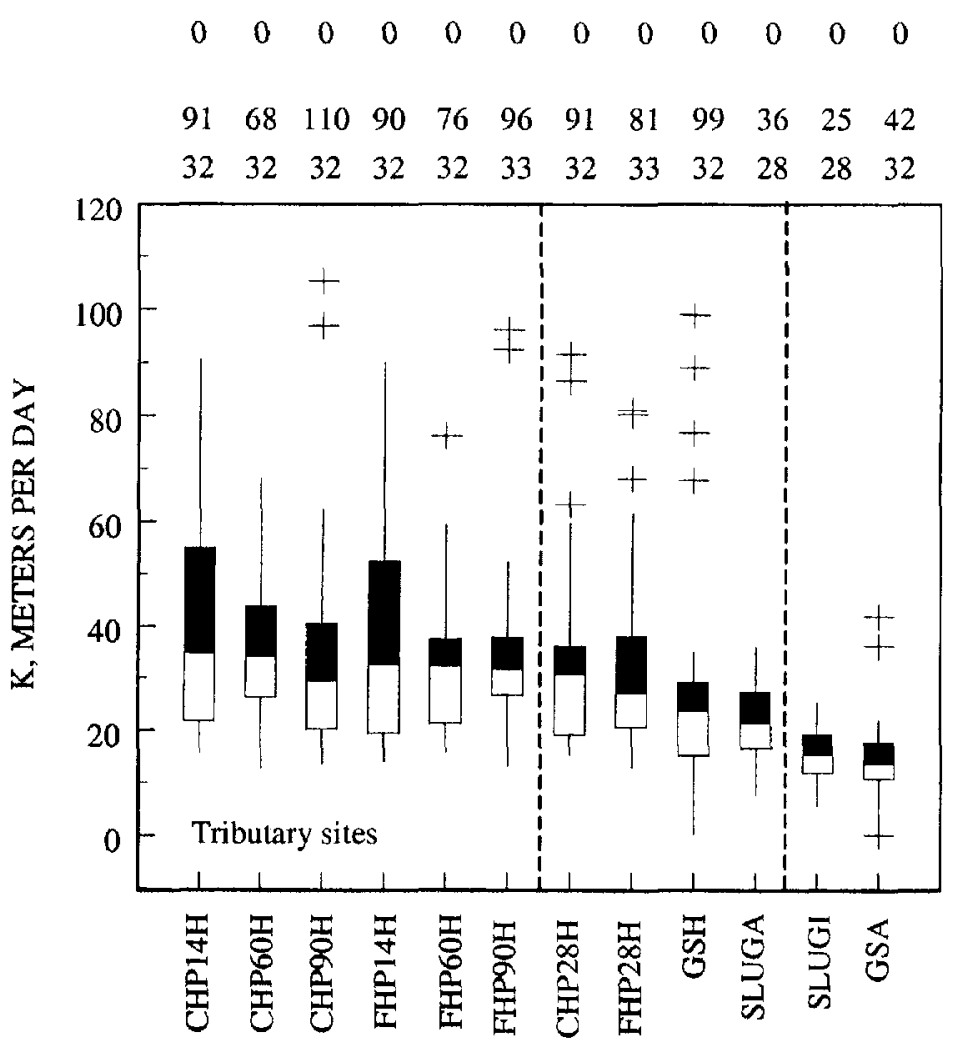

Figure 4. Box plots showing hydraulic conductivity values determined using field permeameter tests analyzed using Hvorslev (1951) solutions, empirical grain-size formulas, and slug tests from (a) main-stem and Wood River and (b) tributary sites. The number of tests using each method (n) also is shown. The vertical dashed lines separate groups of tests that generally had significantly different values. Method abbreviations are defined in Table 2.

SEM91 methods failed to yield duplicate $\mathrm{K}_{\mathrm{v}}$ values for $50 \%, 57 \%$, and $62 \%$, respectively, of the attempted duplicate measurements. Because of time constraints, it was generally not possible to attempt more than two measurements with each seepage meter. Individual seepage-meter tests coupled with hydraulic gradient measurements were unsuccessful for determining $\mathrm{K}_{\mathrm{v}}$ values about $40 \%$ of the time. Values of $\mathrm{K}_{\mathrm{v}}$ determined with different diameters of seepage meter were not significantly different (Figure 3, Table 4).

Several factors contributed to the relatively high rate of failure to obtain $\mathrm{K}_{v}$ values. Of the failed measurements, $58 \%$ were caused by ground water/surface water gradients measured with the potentiomanometer being opposite the flux direction indicated by gains or losses from the seepage bag. This result could have multiple causes related to the seepage-meter measurements, including flow-field deflection caused by frictional resistance of the meter (Erickson 1981; Belanger and Montgomery 1992), stream velocity effects on the bag resulting in deformation or relaxation of the submerged bags (Erickson 1981; Shaw and Prepas 1990; Belanger and Montgomery 1992), leakage between the seepage meters and surface water related to setting and sealing meters into the bottom (Welch et al. 1989; Belanger and Montgomery 1992), or combinations of these variables. At the only site (PS) where head gradients consistently indicated the stream was losing water, measured seepage-meter fluxes were consistently in the opposite direction of the measured gradient. This result suggests that the seepage-meter measurements were not successful under conditions with downward head gradients. Although potentiomanometer measurements are simpler and have fewer sources of error than seepage meters, head gradients were often spatially variable across the stream and temporally variable in response to stream fluctuations, including some cases of reversals during the seepage-meter measurements. Thus, uncertainty in the head gradients contributed, to a lesser extent than the seepage meter measurements, to problems calculating $\mathrm{K}_{v}$ values from the coupled measurements.

Holes in seepage meter bags caused $18 \%$ of the failures. Bedload deposition on top of the collection bag, thereby preventing the bag from changing volume freely, caused $11 \%$ of the failures in spite of the shelters installed to protect the measurement bags. The sediment entered the shelter through holes in the top and ends of the shelter. Holes in other parts of the seepage meter and procedural errors caused $10 \%$ of the failures. Scouring of the bed away from the side of the seepage meter such that the seal of the meter into the bed was broken caused $3 \%$ of the failures, a source of error also discussed by Welch et al. (1989).

\section{Slug Tests}

Duplicate slug tests with the same displacement were not significantly different, indicating the slug-test results were reproducible under the imposed test conditions (Table 3). However, there are several substantial sources of uncertainty in the slug-test $K_{h}$ values.

The semilog data plots for many of the tests showed an approximately linear segment relatively early in the test followed by a second, longer linear segment with a greater slope. This concave-downward response curve with a break in the slope near the beginning of the test could reflect several factors. Such a response is consistent with the occurrence of a low-K "skin" near the well screen (Butler 1998) caused by mobilized or concentrated fine-particles that modify formation char- 


\section{Table 4}

Results of Sign Tests to Determine Significance of Differences in Hydraulic Conductivity Values Between Different Methods and Median Differences

\begin{tabular}{|c|c|c|c|c|c|c|c|c|c|c|c|c|c|c|c|c|c|c|c|c|c|c|c|}
\hline & & $0^{48}$ & $0^{4}$ & $d^{8}$ & $0^{8}$ & $\sigma^{8}$ & $d^{8}$ & $\sigma^{8}$ & $x^{2}$ & $Q^{8}$ & $\mathrm{~s}^{8}$ & $\Delta^{8}$ & $\mathrm{r}^{8}$ & $\alpha^{8}$ & $\alpha^{8}$ & $\alpha^{8}$ & $5^{4}$ & 5 & $s^{2}$ & $0^{s^{\lambda}}$ & $5^{5^{p}}$ & 5 & $5^{2}$ \\
\hline$\overline{\mathrm{CHP} 14 \mathrm{D}}$ & & 74 & 73 & 74 & 74 & 74 & 73 & $\overline{73}$ & 74 & 74 & 74 & 74 & 74 & 74 & 73 & 74 & 35 & 34 & 23 & 72 & 72 & 28 & 28 \\
\hline $\mathrm{CHP}_{28 \mathrm{D}}$ & 0.00 & & 75 & 76 & 76 & 76 & 75 & 76 & 76 & 76 & 76 & 76 & 76 & 76 & 76 & 76 & 35 & 34 & 23 & 74 & 74 & 28 & 28 \\
\hline CHPGOD & 0.00 & 0.00 & & 75 & 75 & 75 & 75 & 75 & 75 & 75 & 75 & 75 & 75 & 75 & 75 & 74 & 35 & 34 & 23 & 73 & 73 & 28 & 28 \\
\hline CHP90D & 0.00 & 0.00 & 0.00 & & 76 & 76 & 75 & 77 & 75 & 76 & 76 & 76 & 76 & 76 & 76 & 76 & 35 & 34 & 23 & 74 & 74 & 28 & 28 \\
\hline $\mathrm{CHP} 14 \mathrm{H}$ & 0.00 & 0.00 & 0.00 & 0.00 & & 76 & 75 & 76 & 76 & 76 & 76 & 76 & 76 & 76 & 76 & 76 & 35 & 34 & 23 & 74 & 74 & 28 & 28 \\
\hline $\mathrm{CHP28H}$ & 0.05 & 0.00 & 0.00 & 0.00 & 0.01 & & 75 & 76 & 76 & 76 & 76 & 76 & 76 & 76 & 76 & 76 & 35 & 34 & 23 & 74 & 74 & 28 & 28 \\
\hline $\mathrm{CHP} 60 \mathrm{H}$ & 0.00 & 0.00 & 0.00 & 0.00 & 0.36 & 0.04 & & 75 & 75 & 75 & 75 & 75 & 75 & 75 & 75 & 75 & 35 & 34 & 23 & 73 & 73 & 28 & 28 \\
\hline $\mathrm{CHP} 90 \mathrm{H}$ & 0.03 & 0.00 & 0.00 & 0.00 & 0.42 & 0.42 & 0.11 & & 76 & 76 & 76 & 76 & 76 & 76 & 76 & 76 & 35 & 34 & 23 & 74 & 74 & 28 & 28 \\
\hline FHP $14 \mathrm{D}$ & 0.00 & 0.00 & 0.00 & 0.00 & 0.00 & 0.00 & 0.00 & 0.00 & & 77 & 76 & 76 & 77 & 77 & 76 & 76 & 35 & 34 & 23 & 74 & 74 & 28 & 28 \\
\hline FHP28D & 0.00 & 0.73 & 0.00 & 0.00 & 0.00 & 0.00 & 0.00 & 0.00 & 0.00 & & 76 & 77 & 77 & 79 & 76 & 77 & 35 & 34 & 23 & 74 & 74 & 28 & 28 \\
\hline FHP60D & 0.00 & 0.00 & 0.17 & 0.00 & 0.00 & 0.00 & 0.00 & 0.00 & 0.00 & 0.00 & & 76 & 76 & 76 & 76 & 76 & 35 & 34 & 23 & 74 & 74 & 28 & 28 \\
\hline FHPGOD & 0.00 & 0.00 & 0.00 & 0.00 & 0.00 & 0.00 & 0.00 & 0.00 & 0.00 & 0.00 & 0.00 & & 76 & 77 & 76 & 77 & 35 & 34 & 23 & 74 & 74 & 28 & 28 \\
\hline FHP14H & 0.00 & 0.00 & 0.00 & 0.00 & 0.00 & 1.00 & 0.17 & 0.30 & 0.00 & 0.00 & 0.00 & 0.00 & & 77 & 76 & 76 & 35 & 34 & 23 & 73 & 74 & 28 & 28 \\
\hline FHP28H & 0.73 & 0.00 & 0.00 & 0.00 & 0.00 & 0.14 & 0.01 & 0.08 & 0.25 & 0.00 & 0.00 & 0.00 & 0.01 & & 76 & 77 & 35 & 34 & 23 & 74 & 74 & 28 & 28 \\
\hline $\mathrm{FHP} 60 \mathrm{H}$ & 0.02 & 0.00 & 0.00 & 0.00 & 0.57 & 0.05 & 0.25 & 1.00 & 0.00 & 0.00 & 0.00 & 0.00 & 0.08 & 0.00 & & 76 & 35 & 34 & 23 & 74 & 74 & 28 & 28 \\
\hline FHP9OH & 0.01 & 0.00 & 0.00 & 0.00 & 0.42 & 0.00 & 0.25 & 0.02 & 0.00 & 0.00 & 0.00 & 0.00 & 0.08 & 0.00 & 0.08 & & 35 & 34 & 23 & 74 & 74 & 28 & 28 \\
\hline SEM28 & 0.00 & 0.00 & 0.00 & 0.01 & 0.00 & 0.00 & 0.00 & 0.00 & 0.00 & 0.00 & 0.00 & 0.01 & 0.00 & 0.00 & 0.00 & 0.00 & & 24 & 13 & 34 & 34 & 16 & 16 \\
\hline SEM61 & 0.00 & 0.00 & 0.00 & 0.00 & 0.00 & 0.00 & 0.00 & 0.00 & 0.00 & 0.00 & 0.00 & 0.00 & 0.00 & 0.00 & 0.00 & 0.00 & 0.31 & & 17 & 32 & 32 & 20 & 20 \\
\hline SEM91 & 0.00 & 0.00 & 0.00 & 0.00 & 0.00 & 0.00 & 0.00 & 0.00 & 0.00 & 0.00 & 0.00 & 0.00 & 0.00 & 0.00 & 0.00 & 0.00 & 0.58 & 0.14 & & 21 & 21 & 8 & 8 \\
\hline GSH & 0.91 & 0.00 & 0.00 & 0.00 & 0.00 & 0.42 & 0.00 & 0.03 & 0.56 & 0.00 & 0.00 & 0.00 & 0.03 & 0.73 & 0.00 & 0.00 & 0.00 & 0.00 & 0.00 & & 74 & 28 & 28 \\
\hline GSA & 0.00 & 0.00 & 0.00 & 0.13 & 0.00 & 0.00 & 0.00 & 0.00 & 0.00 & 0.00 & 0.05 & 0.20 & 0.00 & 0.00 & 0.00 & 0.00 & 0.01 & 0.00 & 0.00 & 0.00 & & 28 & 28 \\
\hline SLUGI & 0.00 & 0.04 & 1.00 & 0.01 & 0.00 & 0.00 & 0.00 & 0.00 & 0.00 & 0.34 & 0.57 & 0.04 & 0.00 & 0.00 & 0.00 & 0.00 & 0.08 & 0.00 & 0.01 & 0.00 & 0.04 & & 28 \\
\hline SLUGA & 0.00 & 0.85 & 0.01 & 0.00 & 0.00 & 0.04 & 0.00 & 0.09 & 0.09 & 0.18 & 0.04 & 0.00 & 0.00 & 0.34 & 0.00 & 0.00 & 0.00 & 0.00 & 0.01 & 0.85 & 0.00 & 0.00 & \\
\hline
\end{tabular}

Significance level (p-value) for two-sided sign tests (lower lefi) and number of observations (upper right) are shown. Significance criteria: $p<0.05$.

Median Differences (in $\mathbf{m} / \mathbf{d a y})\left(K_{s}\right.$ of Test on $X$-axis $-K_{s}$ of Test on y-axis)

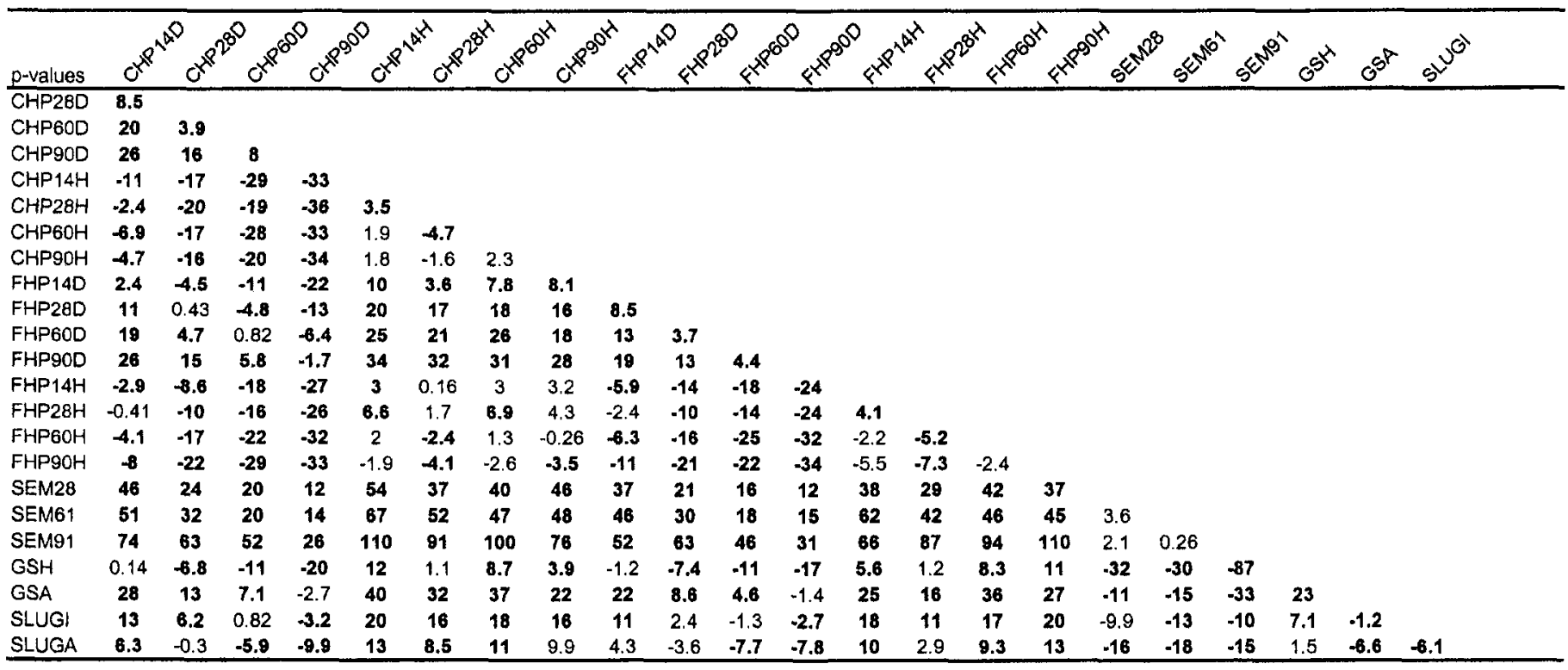

Bold values indicate statistically signilicant differences.

acteristics in the vicinity of the well screen. The slope break also may reflect that the relatively small casing diameter or open area of the screen restricted the early-time response during the displacements (which were relatively large considering the shallow well depths) and high velocities at the beginning of the tests, resulting in frictional head losses in the well. The presence of a low-K skin or frictional losses with the well creates substantial uncertainty in estimated $K_{h}$ values using the Bouwer and Rice method (Butler 1998). A straight line was fit to the middle or second linear segment to estimate $\mathrm{K}_{\mathrm{h}}$, an approach that should yield reasonable estimates of $\mathrm{K}_{h}$ for virtually all values of storativity (Butler 1998). This linear segment suggests that the theoretical conditions of the Bouwer and Rice method were met once the effects of the large early displacements passed. However, the exact effects of a low-K skin or test- design limitations on the $\mathrm{K}_{\mathrm{h}}$ values determined using late-time response data with relatively low displacements are not fully known.

Slug-test data collected at the NS, PB, and WG sites generally could not be analyzed successfully because the response data were oscillatory and exhibited poor fits to theoretical solutions using a modified Springer-Gelhar solution of Zlotnik and McGuire (1998a, 1998b) and a Kipp solution discussed by Weight and Wittman (1999). The poor fit of these tests to theoretical solutions likely resulted from the combination of relatively high displacements, small well diameter, small screen open area, and high K sediments (Butler 1998).

At the tributary sites, the nonoscillatory slug-test response data, and relatively good fits to the theoretical Bouwer and Rice model likely occurred because these sites had relatively lower $\mathrm{K}$ 


\section{K, METERS PER DAY}

0

20

40

60

80

100
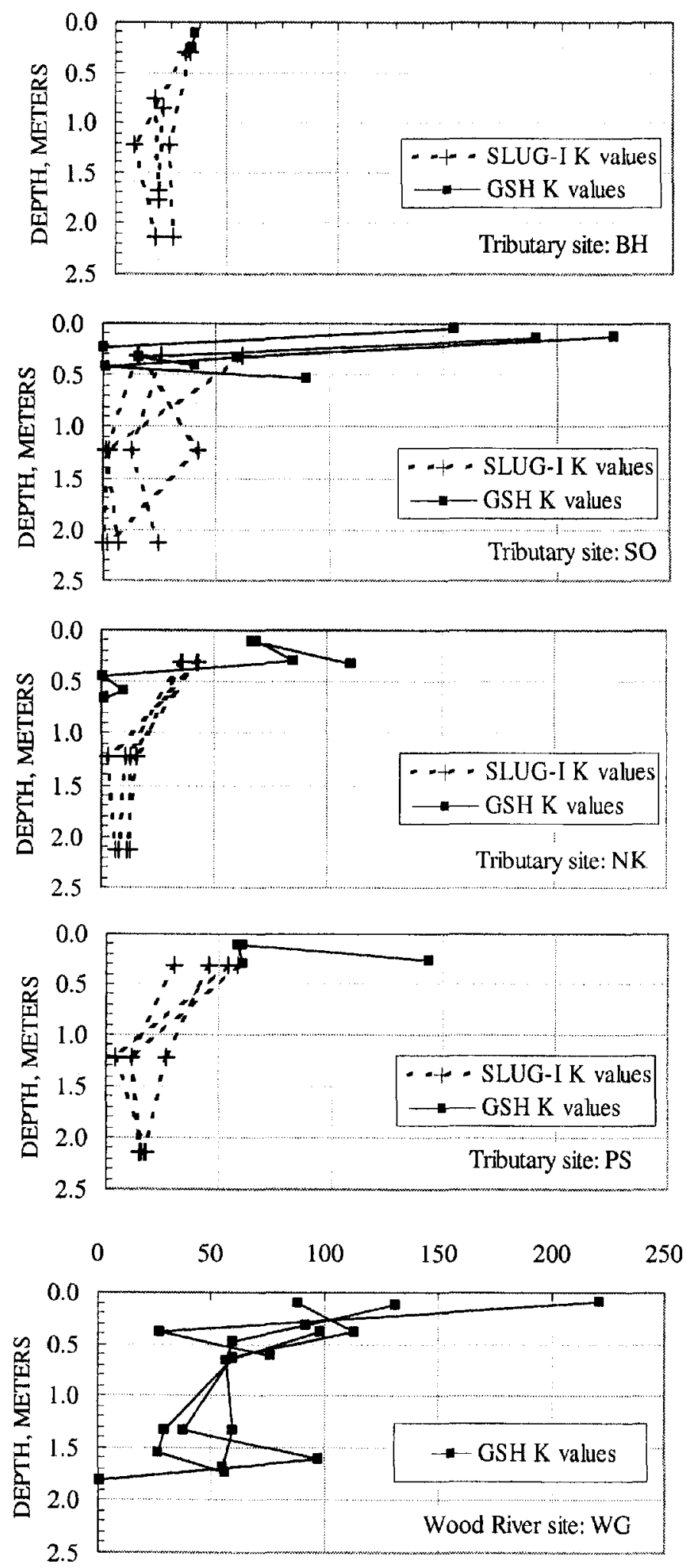

Figure 5. Graphs showing changes in hydraulic conductivity values with depth below the stream bottom at selected locations. Note the change in scale for the WG site. Site abbreviations are defined in Table 1, and method abbreviations are defined in Table 2.

(indicated by slower response times) than the main-stem and Wood River sites. Although reproducible at the displacements used, $K_{h}$ values estimated using the Bouwer and Rice slug tests have substan- tial uncertainty and are included mainly for comparative purposes to other tests.

\section{Grain-Size Analyses}

Although the differences between duplicate tests for the GSH and GSA methods were statistically significant, the median differences between duplicates were less than $1 \mathrm{~m} / \mathrm{day}$, and of little practical importance.

\section{Local Spatial Variability of Sediment Properties}

Local scale spatial variability in streambed properties over distances of less than $3 \mathrm{~m}$ did not have a substantial impact on $\mathrm{K}$ values determined in this study (Table 3 ). This result was somewhat unexpected given that previous studies using seepage meters to measure ground water/surface water fluxes had found that spatial variability over distances less than $2 \mathrm{~m}$ was a major cause of variability in seepage meter measurements in lakes (Shaw and Prepas 1990) and laboratory tank experiments with fine-to-medium sand (Belanger and Montgomery 1992). These spatial variations were interpreted primarily to be the result of spatial variations in hydraulic conductivity caused by sedimentary heterogeneity. In this study, median differences between side-by-side tests for all sizes of seepage meters were less than $0.4 \mathrm{~m} /$ day, although measurement failure resulted in the number of comparisons ranging from only 6 to 12 (Table 3). Only one method, FHP14H, had significant differences in $\mathrm{K}_{\mathrm{v}}$ values for side-by-side tests. The reason for this result is unclear.

\section{Different Measurement Methods}

Because the results of field permeameter tests analyzed with the Darcy equation were dependent upon diameter and coupled seepage meter/hydraulic gradient measurements had a relatively high incidence of failure, neither was a preferred approach for determining $\mathrm{K}$ under the conditions encountered in this study. The remaining methods, including field permeameter tests analyzed with the Hvorslev solutions, empirical grain-size methods, and slug tests, are compared in this section for determining $\mathrm{K}$ in the upper 0.2 to $0.3 \mathrm{~m}$ of the streambed. At depths greater than about $0.3 \mathrm{~m}$, field permeameter and seepage meter tests could not be used to measure $\mathrm{K}$; therefore, $\mathrm{K}$ values estimated from grain-size and slug tests at greater depths are excluded from the comparisons discussed in this section.

The remaining methods were grouped such that most of the comparisons between methods in each group indicated that the results were statistically similar. Falling- and constant-head tests with the 14,60 , and $90 \mathrm{~cm}$ diameter field permeameters analyzed with the Hvorslev solutions generally had similar K values (Figure 4, Table 4). Comparisons between these tests indicated that they were not significantly different with the exception of comparisons between the $\mathrm{CHP} 90 \mathrm{H}$ and FHP9OH and the CHP14H and FHP14H tests. These Hvorslev field permeameter tests generally had significantly higher $\mathrm{K}$ than grain-size and slug-test analyses (Figure 4, Table 4). Values of $\mathrm{K}$ determined with CHP28H, FHP28H, GSH, and SLUG-A tests were not significantly different, with the exception of comparisons between the FHP28H and SLUG-A tests. Values for these tests were intermediate between values from most Hvorslev permeameter tests, which were greater, and values determined from SLUG-I and GSA tests, which were less.

The Hvorslev permeameter tests should be a more rigorous approach to determine $\mathbf{K}$ compared to grain-size tests because 

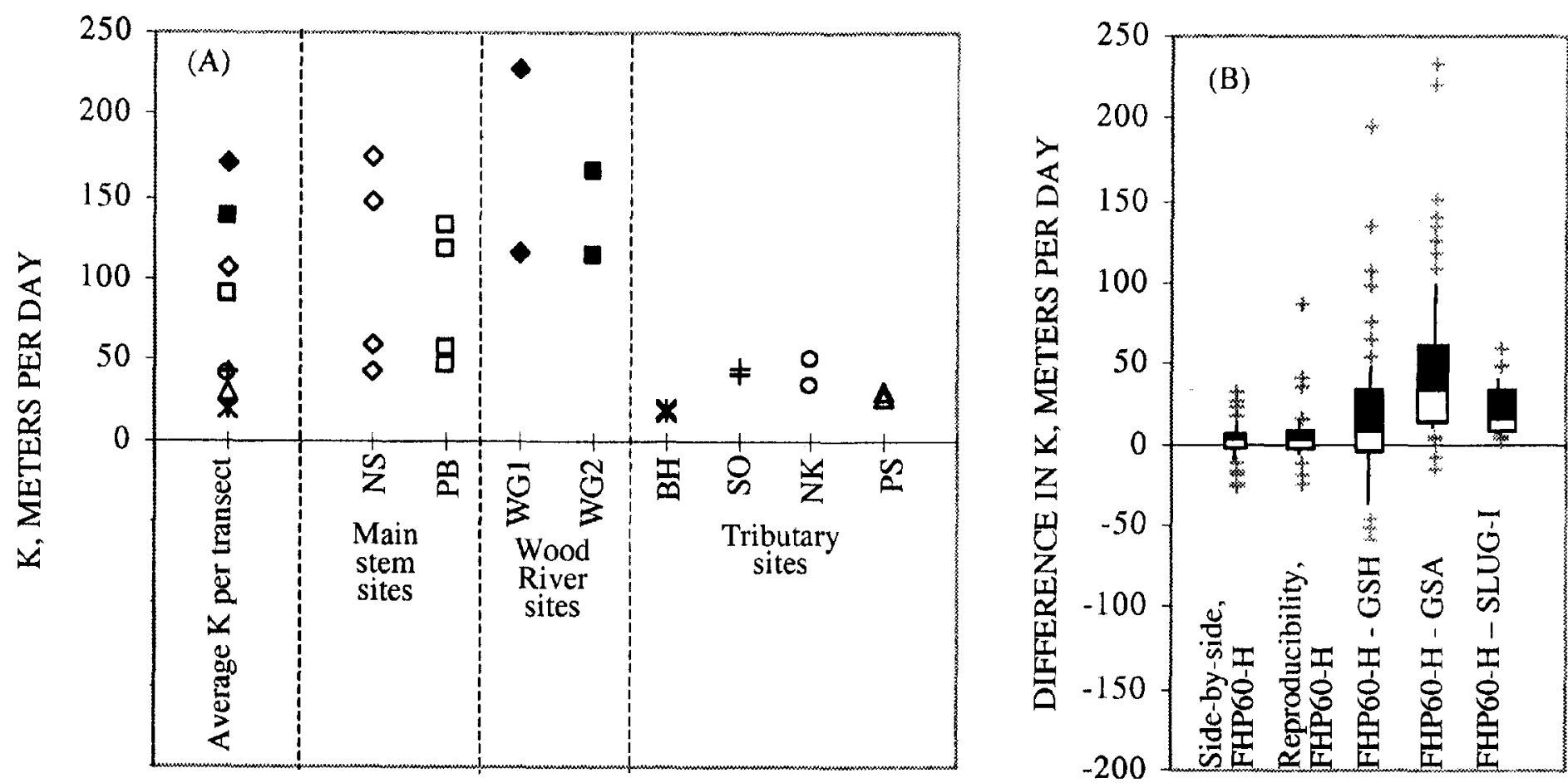

Figure 6. Graphs comparing (a) spatial variability of hydraulic conductivity values of the upper $0.25 \mathrm{~m}$ measured using the $60 \mathrm{~cm}$ falling-head permeameter test analyzed using the Hvorslev equation (FHP60H); (b) variability caused by local scale spatial variability (side-by-side tests for the FHP60H method), measurement imprecision (reproducibility tests for the FHP60H method), and different methods of measurement (differences between the FHP60H and Hazen grain size (GSH), Alyamani and Sen grain size (GSA), and slug test (assuming isotropic conditions, SLUG-I) methods). The FHP60H is used as the standard test for comparison because it is the preferred method for use in the upper $0.25 \mathrm{~m}$ identified in this study (see Implications for Additional Data Collection). Site abbreviations are defined in Table 1 and method abbreviations are defined in Table 2.

they are field hydraulic analyses rather than empirical relations of grain-size to $\mathrm{K}$. The results of this investigation are consistent with those of previous studies in sandy aquifers (Wolf et al. 1991a; Millham and Howes 1995; Rovey and Cherkauer 1995) indicating that $\mathrm{K}$ values estimated from empirical grain-size formulas are generally less than those determined from field hydraulic testing. These previous studies principally attributed the differences to the larger measurement scale of the field tests. However, $\mathrm{K}$ values calculated using the grain-size methods may be smaller because $\mathrm{K}$ is a complex function of packing, sediment structure, heterogeneity, and other factors not accounted for in the empirical grain-size methods (Taylor et al. 1990).

Values of $\mathrm{K}$ determined from slug tests were likely lower than those computed using Hvorslev permeameter tests because the screened interval of 0.07 to $0.54 \mathrm{~m}$ of the slug test intersected lower $\mathrm{K}$ sediments than the permeameter tests of the upper $0.25 \mathrm{~m}$, and possibly because of greater well-skin effects on the slug-test results. At the tributary sites, $\mathrm{K}$ generally decreased with depth (Figure 5). At four locations where grain-size depth profiles with multiple samples over the slug test screened interval were available, $\mathrm{K}$ values were calculated for the upper $0.25 \mathrm{~m}$ and the 0.07 to $0.54 \mathrm{~m}$ depth using the harmonic means of GSH K values. For these four cases, vertically averaged $\mathrm{K}$ in the upper $0.25 \mathrm{~m}\left(\mathrm{~K}_{0-2.5}\right)$ was 1.5 to 12 times greater than over the 0.07 to $0.54 \mathrm{~m}$ interval $\left(\mathrm{K}_{7-54}\right)$. These vertical changes in $\mathrm{K}$ were similar to the median ratio of $\mathrm{FHP} 60 \mathrm{H}$ to slug-test values of 2.2 for the slug-test results analyzed assuming isotropic conditions and 1.6 for anisotropic conditions $\left(\mathrm{K}_{\mathrm{h}} / \mathrm{K}_{\mathrm{Z}}=10\right)$. The similarity of the ratios of $\mathrm{K}_{0-25} / \mathrm{K}_{7-54}$ and $\mathrm{K}_{\mathrm{FHP60H}} / \mathrm{K}_{\text {slug }}$ indicates that much of the difference between permeameter and slug-test values could be explained by the inherent variation in $\mathrm{K}$ with depth.

Well-skin and test-design effects may be less of a concern for permeameter tests than slug tests. Butler (1998) recommends that the results of slug tests be viewed as lower bounds of the estimated $\mathrm{K}$ because of the prevalence of low-K well skin effects. For slug tests in screened wells driven into the sediment, the entire length of the well screen is in contact with sediment potentially disturbed during the driving process. Although driving wells minimizes formation disturbance relative to other drilling methods (Morin et al. 1988), disturbance can still occur because of smearing of fine particles along the casing, compaction of sediments in the vicinity of the driven pipe, and penetration of soil structure. Alternatively, slug-test values may have been reduced because of the combination of the small diameter of the wells and the relatively large displacements used for the slug testing. Head losses in the narrow diameter wells may have been sufficient to decrease the calculated $\mathrm{K}$, especially in relatively high-K sediments (Butler 1998, pp. 168-169). Slope breaks in the slug-test response curves that may indicate either well-skin or test-design effects were sometimes observed. In contrast, permeameters do not have a well screen through which flow will be restricted by fine materials. In addition, disturbance of sediment during installation generally will be less for the permeameters than the slug tests, especially for larger diameters, because sediment disturbance will occur only along the walls of the permeameter. The volume of undisturbed sediment in the middle of the permeameter will be relatively large in comparison with the volume of disturbed sediment along the permeameter walls.

It is unlikely that the differences between the Hvorslev permeameter and Bouwer and Rice slug tests can be attributed only to the fact that the former measures $K_{v}$ whereas the latter measures $K_{h}$. Anisotropy ratios $\left(\mathrm{K}_{\mathrm{h}} / \mathrm{K}_{\mathrm{v}}\right)$ calculated by dividing slug-test values by Hvorslev permeameter values ranged from about 0.1 to 1.3 with an average of 0.6 . Anisotropy ratios of less than one are contrary to typ- 
ical literature values from one to 100 (Freeze and Cherry 1979; Butler 1998; Chen and Yin 1999). Rather than indicating that the anisotropy ratio in the upper $0.25 \mathrm{~m}$ of the streambed was actually less than 1.0 , it is more likely that these differences reflected differences in testing intervals, sedimentary disturbance, or test design between the Hvorslev permeameter and Bouwer and Rice slug tests.

The actual anisotropy ratios of the streambed sediments were uncertain. Chen and Yin (1999) determined that aquifer anisotropy ratios have a substantial effect upon modeled streamflow depletion. The streambed sediments in the upper $0.25 \mathrm{~m}$ generally comprise more than $99 \%$ sand and gravel-sized particles that were well rounded. In such sediments, local anisotropy is expected to be minimal. Therefore, for the Hvorslev permeameter calculations, isotropic conditions $\left(\mathrm{K}_{\mathrm{h}} / \mathrm{K}_{\mathrm{v}}=1\right)$ were assumed in the upper $0.25 \mathrm{~m}$. However, the Wood River and tributary sites had vertical variations in grain size (Table 1) and this sedimentary layering could result in anisotropic conditions below the upper $0.3 \mathrm{~m}$. The screened interval of the slug tests spanned some of these lithologic layers. Thus, it is likely that anisotropy affected the slug-test responses. Slug-test $\mathrm{K}$ values were calculated assuming $\mathrm{K}_{\mathrm{h}} / \mathrm{K}_{\mathrm{v}}$ values of one for the Bouwer and Rice (1976) method and 10 for the Zlotnik (1994) extension of the Bouwer and Rice method. These values of $\mathrm{K}_{\mathrm{h}} / \mathrm{K}_{\mathrm{v}}$ represent the typical range for relatively small-scale tests (Freeze and Cherry 1979; Butler 1998) and were selected to bound the expected effects of anisotropy on $\mathrm{K}_{\mathrm{h}}$ values. Values of $\mathrm{K}_{\mathrm{h}}$ were an average of $40 \%$ higher when $\mathrm{K}_{\mathrm{h}} / \mathrm{K}_{\mathrm{v}}$ was assumed to be 10 than when a value of one was assumed. These variations in slug-test $\mathrm{K}_{\mathrm{h}}$ values due to the assumed anisotropy ratio were not large enough to change the conclusions drawn with respect to the comparison of slug tests to other tests (Figure 4). While the anisotropy ratio cannot be determined from the data collected, the presence of lithologic layering makes it likely that the most reasonable slug-test $\mathrm{K}_{\mathrm{h}}$ values were between the values determined for $\mathrm{K}_{\mathrm{h}} / \mathrm{K}_{\mathrm{v}}$ of one and 10 .

Values of $\mathrm{K}$ estimated using the GSH method were closer than the GSA estimates to values determined using the Hvorslev permeameter tests, which likely represented the best estimate of $\mathrm{K}$ in the upper $0.25 \mathrm{~m}$. Similarly, Sperry and Peirce (1995) determined that $\mathbf{K}$ values estimated with the Hazen method compared more closely to those measured in laboratory column experiments than values estimated using the Alyamani and Sen (1993) method. Calculation of $\mathrm{K}$ values using the Hazen method for grain-size data reported in Alyamani and Sen (1993, Table 1) indicates that the Hazen $\mathrm{K}$ values are consistently greater than Alyamani and Sen values by a median factor of about 1.5 .

Values of $\mathrm{K}$ determined with coupled seepage meter/hydraulicgradient measurements were significantly lower than other methods. Apart from the lack of reliability of these measurements because of high failure rates, lower $\mathrm{K}$ may reflect flow-field deflection caused by frictional resistance in the meter (Erickson 1981; Belanger and Montgomery 1992).

\section{Spatial Variability of Streambed Hydraulic Conductivity}

The main-stem transects have substantial spatial variability in $\mathrm{K}$ of the upper $0.25 \mathrm{~m}$ across the stream (Figure 6). Large spatial variations in streambed properties across a braided river were expected given the complex sedimentary processes occurring (Karlinger et al. 1983; Walker and Cant 1984). While the highest $\mathrm{K}$ values sometimes were found in the deeper channels, the depositional patterns of the Platte River are complex enough that the locations of relatively high $\mathrm{K}$ deposits will not always be predictable.
The Wood River (WG) site also shows a relatively large amount of spatial variation in $\mathrm{K}$ of the upper $0.25 \mathrm{~m}$ across the stream in spite of the relative uniformity of the channel. At the four tributary sites, $\mathrm{K}$ varied little across the stream transects, which may reflect that the channels are only $6 \%$ to $18 \%$ as wide as the PB transect, and that sedimentary processes are more uniform across the channel on the tributaries than on the braided main stem.

The magnitude of spatial variability in $\mathrm{K}$ along the NS, $\mathrm{PB}$, and WG transects is similar to the differences between transects in width-weighted mean K (Figure 6). Regional variations in streambed characteristics were expected based on regional variations in stream slope, discharge, and sediment load (Kircher 1983; Kinzel et al. 1999). For the tributary sites, spatial variation in $K$ values along transects were generally less than variations in mean values between transects.

At the four tributary sites and the Wood River site, $\mathrm{K}$ values determined from grain-size analyses and slug tests were generally greater at or near the streambed interface than at depth (Figure 5). At the SO, NK, and WG sites, grain-size samples collected through the upper $0.6 \mathrm{~m}$ indicated that $\mathrm{K}$ decreased from the upper $0.25 \mathrm{~m}$ to greater depths. Grain-size data was not collected to a sufficient depth to confirm similar decreases below the upper $0.3 \mathrm{~m}$ at the $\mathrm{BH}$ and PS sites. However, $\mathrm{K}$ between the shallowest slug test (with the middle of the screen at about $0.3 \mathrm{~m}$ ) and the next greatest depth (with the middle of the screen at about $1.2 \mathrm{~m}$ ) decreased at all four tributary sites (SO, NK, BH, and PS) (Figure 5). At the NS site (North Platte River), GSH K was highly variable with depth, and no consistent relation was apparent.

\section{Implications for Additional Data Collection}

Using Darcy's equation, calculated ground water/surface water fluxes will be directly proportional to values of streambed $\mathrm{K}$. Thus, it is desirable to have estimates of streambed $\mathrm{K}$ that are as well constrained as possible. More than $50 \%$ of the Hvorslev permeameter, slug test, and grain-size determinations indicated $\mathrm{K}$ values of 50 to $150 \mathrm{~m} /$ day at the main-stem and Wood River sites and 15 to $55 \mathrm{~m} /$ day at the tributary sites (Figure 4). These values represent substantially better constrained estimates of $\mathrm{K}$ than values based upon textural descriptions (Table 1, Freeze and Cherry 1979, p. 29), which range over two orders of magnitude from about 8 to $900 \mathrm{~m} /$ day for the main-stem and Wood River sites and 0.8 to $90 \mathrm{~m} /$ day for tributary sites. Thus, field measurements of streambed $\mathrm{K}$ are useful for constraining initial parameter estimates for ground water/surface water flux calculations.

Field permeameter tests analyzed using Hvorslev solutions have advantages compared to seepage meters, empirical grain-size formulas, and slug tests for determining streambed $\mathrm{K}$ at the streambed interface (approximately the upper $0.3 \mathrm{~m}$ ). Field permeameter tests are easier to conduct, and more consistently successful at determining streambed $\mathrm{K}$ than coupled seepage meter and hydraulic gradient measurements. Because Hvorslev permeameter tests are field hydraulic tests that inherently consider factors such as packing, grain shape, and sedimentary heterogeneity that affect $\mathrm{K}$, these tests are superior to empirical grain-size formulas. Compared to slug tests, Hvorslev permeameter tests are less likely to be influenced by well-skin and test-design effects, and determine $\mathrm{K}_{v}$ through the streambed rather than $\mathrm{K}_{\mathrm{h}}$ some depth below the streambed.

The problems encountered in this study with determining $K_{v}$ with coupled seepage-meter and hydraulic-gradient measurements were related principally to the relatively high-energy environment 
in which the measurements were attempted and the fact that two independent measurements had to be made to calculate $\mathrm{K}_{\mathrm{v}}$. Although the shelters installed to protect the measurement bags offered greater protection than leaving the bags in open water, the shelters did not entirely prevent water velocity or sediment deposition effects on the measurement bags. Uncertainties in seepage meter and ground water/surface water gradient measurements were compounded in trying to estimate $K_{\mathrm{v}}$. Seepage meters have been used widely for measuring ground water/surface water fluxes in low energy settings such as lakes and are a very useful method in these settings (Lee 1977; Fellows and Brezonik 1980; Erickson 1981; Cherkauer and McBride 1988; Welch et al. 1989; Shaw and Prepas 1990; Belanger and Montgomery 1992). This study suggests that there may be limited applicability for seepage meters to measure seepage flux and coupled seepage-meter and hydraulic-gradient measurements to determine $K_{v}$ in relatively high-energy flowing streams with mobile beds.

While the Hvorslev falling-head permeameter test may be an advantageous test for determining $\mathrm{K}$ at the streambed interface, slug tests and empirical grain-size methods should not be discredited as approaches for determination of streambed $\mathrm{K}$. Although statistically different, median differences in $\mathrm{K}$ values between the FHP60H method and the GSH, SLUGA, SLUGI, and GSA methods were about $8,9,17$, and $35 \mathrm{~m} /$ day, respectively (Table 4 ). These differences in $\mathrm{K}$ values were not particularly large considering typical uncertainties in $\mathrm{K}$ values of an order of magnitude or more due to heterogeneity and scale (Freeze and Cherry 1979; Eggleston and Rojstaczer 1998). While it is desirable to have estimates of streambed $\mathrm{K}$ that are as well constrained as possible, spatial variations in K over a variety of hydrogeologic scales may make variability in $\mathrm{K}$ caused by the method of measurement a comparatively minor source of uncertainty in $\mathrm{K}$ values. Selecting a method that can feasibly be applied to generate consistently determined data and identify relative variations in streambed $\mathrm{K}$ across the study area is probably of greater importance than method selection between valid field permeameter, grain-size, and slug tests.

Spatial variability of $\mathrm{K}$ across streams and with depth also needs to be considered in selecting an instream method of measuring K. Spatial variability along and between transects was generally greater than variability in $\mathrm{K}$ because of measurement uncertainty for each method (particularly for the preferred permeameter methods), or local scale (side-by-side) variability of streambed sediments (Figure 6). Spatial variability in $\mathrm{K}$ was also generally greater than variability between methods (Figure 6). This result implies that choice of method between valid permeameter, grainsize, or slug-test analyses may not be as significant as making multiple measurements to characterize the variability across transects.

The streambed interface was not a low $\mathrm{K}$ layer relative to underlying deposits, as has commonly been found (Conrad and Beljin 1996), on any of the streams measured. At the Wood River and tributary sites, the streambed interface typically had greater $\mathrm{K}$ than the sediments below. It is probable that deposits deeper than about $0.3 \mathrm{~m}$ below the streambed interface limit the rate of ground water/surface water interaction. However, the Hvorslev permeameter tests are not a practical approach for determining $\mathrm{K}$ at these depths because the permeameters cannot be driven to or retrieved from these depths easily. The $\mathrm{K}$ of these buried streambed deposits could be determined by conducting slug tests or analyzing core samples for grain-size distribution.
The main advantages of instream methods of measuring $\mathrm{K}$ are that the measurements are relatively quick and inexpensive, and can be used to make many measurements to characterize variations in $\mathrm{K}$ across a regional study area. However, there are logistical limitations for instream methods, chiefly, access to the stream. It was practically impossible to make measurements in streams with water depth greater than about $1 \mathrm{~m}$, or with water velocities greater than about $0.8 \mathrm{~m} / \mathrm{sec}$. Relatively high flows in the South Platte and Platte Rivers from August through October 1999 resulted in water depths and velocities greater than these practical thresholds, and prevented additional instream measurements from being made on these rivers. These constraints may limit the utility of instream measurements in some cases, and may require alternative methods such as analysis of pump tests or bank-storage effects near streams.

\section{Conclusions}

Estimates of streambed $\mathrm{K}$ are needed to quantify the magnitude and spatial distribution of ground water/surface water interactions. Physical instream methods offer a practical approach for characterizing K over regional study areas because the measurements are relatively quick and inexpensive and numerous measurements can be made at many locations using portable equipment. Comparisons of $\mathrm{K}$ values determined in sandy streambeds at seven stream transects in the Platte River Basin in Nebraska using different instream measurement techniques indicate the following conclusions.

1. Field permeameter tests analyzed using the Darcy equation and coupled seepage meter/hydraulic-gradient measurements were not preferred techniques based upon test design and logistical concerns; seepage meters often fail in relatively high-energy flowing streams with mobile beds.

2. The Hvorslev analysis of field permeameter tests has advantages compared with other methods for determining $\mathrm{K}$ in the upper $0.25 \mathrm{~m}$ of the streambed.

3. Measurement precision and local spatial variability over distances of less than $3 \mathrm{~m}$ were very minor to negligible sources of variation in $\mathrm{K}$.

4. Spatial variability along and between transects on the Platte, North Platte, and Wood Rivers was greater than variability in $\mathrm{K}$ values between methods. Thus, selection of a method between valid permeameter, grain-size, or slug-test analyses may matter less than making multiple measurements to characterize the variability across transects adequately.

5. When selecting a method for measuring streambed $\mathrm{K}$, the vertical location of the low-permeability sediments needs to be considered. The streambed was not a low $\mathrm{K}$ layer on any of the streams investigated. On tributary streams, the deposits deeper than about $0.3 \mathrm{~m}$ below the streambed probably limited ground water/surface water fluxes. The Hvorslev permeameter tests are not a practical measurement approach below $0.3 \mathrm{~m}$ because the permeameters cannot be driven to and retrieved from these depths easily. Slug tests or collection of core samples represent more practical instream approaches for determining the $\mathrm{K}$ of these buried deposits.

\section{Acknowledgments}

The Nebraska Cooperative Hydrology Study Group (COHYST) and the U.S. Geological Survey funded this study. The authors 
thank the COHYST group for extensive logistical and planning support. The authors also thank Virginia McGuire, Scott Christenson, and Mike Turco, U.S. Geological Survey, and Vitaly Zlotnik and Brian Zurbruchen, University of Nebraska, Department of Geosciences, for assistance with slug tests, and D.O. Rosenberry and R.J. Hunt, U.S. Geological Survey, and journal reviewers for their helpful comments on this manuscript.

The use of trade or product names in this report is for identification purposes only and does not constitute endorsement by the USGS.

Editor's Note: The use of brand names in peer-reviewed papers is for identification purposes only and does not constitute endorsement by the authors, their employers, or the National Ground Water Association.

\section{References}

Alyamani, M.S., and Z. Sen. 1993. Determination of hydraulic conductivity from complete grain-size distribution curves. Ground Water 31 , no. 4: 551-555.

Barlow, P.M., and A.F. Moench. 1998. Analytical solutions and computer programs for hydraulic interaction of stream-aquifer systems. U.S. Geological Survey Open-File Report 98-415A.

Belanger, T.V., and M.T. Montgomery. 1992. Seepage meter errors. Limnology and Oceanography 37, no. 8: 1787-1795.

Bentall, R. 1991. Facts and figures about Nebraska Rivers. Special Supplement to the 1991 Nebraska Water Conference. Conservation and Survey Division, University of Nebraska, Lincoln, Nebraska.

Bouwer, H. 1989. The Bouwer and Rice slug test-An update. Ground Water 27, no. 3, 304-309.

Bouwer, H., and R.C. Rice. 1976. A slug test for determining hydraulic conductivity of unconfined aquifers with completely or partially penetrating wells. Water Resources Research 12, 423-428.

Butler, J.J. 1998. The Design, Performance, and Analysis of Slug Tests. New York: Lewis Publishers.

Butler, J.J., and J.M. Healy. 1998. Relationship between pumping-test and slug-test parameters: Scale effect or artifact? Ground Water 36, no. 2: 305-313.

Cey, E.E., D.L. Rudolph, G.W. Parkin, and R. Aravena. 1998. Quantifying groundwater discharge to a small perennial stream in southern Ontario, Canada. Journal of Hydrology 210, nos. 1-4: 31-37.

Chen X., and Y. Yin. 1999. Evaluation of streamflow depletion for vertical anisotropic aquifers. Journal of Environmental Systems 27, no. 1: 55-70.

Cherkauer, D.A., and J.M. McBride. 1988. A remotely operated seepage meter for use in large lakes and rivers. Ground Water 26, no. 2: 165-171.

Conrad, L.P., and M.S. Beljin. 1996. Evaluation of an induced infiltration model as applied to glacial aquifer systems. Water Resources Bulletin 32, no. 6: $1209-1220$.

COHYST. 2000. Nebraska COoperative HYdrology STudy Group Website: http://cohyst.nrc.state.ne.us. Accessed March 20, 2000.

Duwelius, R.F. 1996. Hydraulic conductivity of the streambed, East Branch Grand Calumet River, Northern Lake County, Indiana. U.S. Geological Survey Water-Resources Investigations Report 96-4218.

Edwards, T.K., and G.D. Glysson. 1988. Field methods for measurement of fluvial sediment. U.S. Geological Survey Open-File Report $86-531$.

Eggleston, J,, and S. Rojstaczer, 1998. Identification of large-scale hydraulic conductivity trends and the influence of trends on contaminant transport. Water Resources Research 34, no, 9: 2155-2168.

Erickson, D.R. 1981. The hydrogeology of Williams Lake, Minnesota with special emphasis on quantification of littoral ground water contributions using seepage meters and wells. M.S. thesis, Department of Geology and Geophysics, University of Minnesota.

Eschner, T.R., R.F. Hadley, and K.D. Crowley. 1983. Hydrologic and morphologic changes in channels of the Platte River Basin in Colorado, Wyoming, and Nebraska: A historical perspective. U.S. Geological Survey Professional Paper 1277-A.
Fadl, A.E. 1979. A modified permeameter for measuring hydraulic conductivity of soils. Soil Science 128, no. 2: 126-128.

Fellows, C.R., and P.L. Brezonik. 1980. Seepage flow into Florida lakes. Water Resources Bulletin 16, no. 4: 635-641.

Freeze, R.A., and J.A. Cherry. 1979. Groundwater. Englewood Cliffs, New Jersey: Prentice-Hall Inc.

Hantush, M.S. 1965. Wells near streams with semipervious beds. Journal of Geophysical Research 70, no. 12: 2829-2838

Hart, D.R., P.J. Mulholland, E.R. Marzolf, D.L. DeAngelis, and S.P. Hendricks. 1999. Relationships between hydraulic parameters in a small stream under varying flow and seasonal conditions. Hydrological Processes 13, no. 10: 1497-1510.

Harvey, J.W., and K.E. Bencala. 1993. The effect of streambed topography on surface-subsurface water exchange in mountain catchments. Water Resources Research 29, no. 1: 89-98.

Hazen, A. 1893. Some physical properties of sands and gravels. Massachusetts State Board of Health, 24th Annual Report.

Helsel, D.R., and R.M. Hirsch. 1992. Statistical Methods in Water Resources. Studies in Environmental Science 49. Amsterdam, The Netherlands: Elsevier Science Publishers.

Hill, R.L., and L.D. King. 1982. A permeameter which eliminates boundary flow errors in saturated hydraulic conductivity measurements. Journal of the Soil Science Society of America 46, no. 4: 877-880.

Hunt, B. 1999. Unsteady stream depletion from ground water pumping. Ground Water 37, no. 1: 98-102

Hvorslev, M.J. 1951. Time lag and soil permeability in ground-water observations. U.S. Army Waterways Experiment Station Bulletin 36, Vicksburg, Mississippi.

Isiorho, S.A., and J.H. Meyer. 1999. The effects of bag type and meter size on seepage meter measurements. Ground Water 37, no. 3: 411-413.

Karlinger, M.R., T.R. Eschner, R.F. Hadley, and J.E. Kircher. 1983. Relation of channel-width maintenance to sediment transport and river morphology: Platte River, south-central Nebraska. U.S. Geological Survey Professional Paper 1277-E.

Kinzel III, P.J., J.M. Nelson, R.S. Parker, J.P. Bennett, and D.J. Topping. 1999. Grain-size evolution of bed sediment in the Platte River, 1931-98. In Proceedings of the 1999 Platte River Basin Ecosystem Symposium, February 23-24, Kearney, Nebraska. Platte River Watershed Program, University of Nebraska, Lincoln, Nebraska. (http://ianrwww.unl.edu/ianr/pwp/symposium/WEB199_htm.htm)

Kircher, J.E. 1983. Interpretation of sediment data for the South Platte River in Colorado and Nebraska, and the North Platte and Platte Rivers in Nebraska. U.S. Geological Survey Professional Paper 1277-D.

Larkin, R.G., and J.M. Sharp. 1992. On the relationship between river-basin geomorphology, aquifer hydraulics, and ground-water flow direction in alluvial aquifers. Geological Society of America Bulletin 104, no. 12 : $1608-1620$.

Lee, D.R. 1977. A device for measuring seepage flux in lakes and estuaries. Limnology and Oceanography 22, no. 1: 140-147.

Lee, D.R., and J.A. Cherry. 1978. A field exercise on groundwater flow using seepage meters and mini-piezometers. Journal of Geological Education 27, no. 1: 6-10.

Lindgren, R.J., and M.K. Landon. 2000. Effects of ground-water withdrawals on the Rock River and associated valley aquifer, Eastern Rock County, Minnesota. U.S. Geological Survey Water-Resources Investigations Report 99-4157.

Luckey, R.L., and M.F. Becker. 1999. Hydrogeology, water use, and simulation of flow in the High Plains aquifer in northwestern Oklahoma, southeastern Colorado, southwestern Kansas, northeastern New Mexico, and northwestern Texas. U.S. Geological Survey Water-Resources Investigations Report 99-4104.

Mathsoft Inc. 1999. S-Plus 2000 guide to statistics, volume 1. Seattle, Washington: Data Analysis Products Division.

McDonald, M.G., and A.W. Harbaugh. 1988. A modular three-dimensional finite-difference ground-water flow model. U.S. Geological Survey Techniques of Water-Resources Investigations Book 6, Ch. Al.

McMahon, P.B., J.A. Tindall, J.A. Collins, K.J. Hull, and J.R. Nuttle. 1995. Hydrologic and geochemical effects on oxygen uptake in bottom sediments of an effluent-dominated river. Water Resources Research 31 , no. 10: $2561-2569$

Millham, N.P., and B.L. Howes. 1995. A comparison of methods to determine $\mathrm{K}$ in a shallow coastal aquifer. Ground Water 33, no. 1: 49-57. 
Morin, R.H., D.R. LeBlanc, and W.E. Teasdale. 1988. A statistical evaluation of formation disturbance produced by well-casing installation methods. Ground Water 26, no. 2: 207-217.

Petersen, T.A., D.S. Armstrong, J.R. Stark, and D.S. Hansen. 1995. Spatial variability of streambed properties related to stream-channel geomorphology and base flow of a gaining stream in glaciated north central Minnesota. In Water Resources at Risk, ed. W.R. Hotchkiss, J.S. Downey, E.D. Gutentag, and J.E. Moore, LL141-LL153. Denver, Colorado, American Institute of Hydrology.

Rosenberry, D.O., 2000, Unsaturated-zone wedge beneath a large, natural lake. Water Resources Research 36, no. 12: 3401-3409.

Rosenshein, J.S. 1988. Hydrology of North America, Region 18, Alluvial valleys. In The Geology of North America, ed, W. Back, J.S. Rosenshein, and P.R. Seaber, O-2, 165-176. Boulder, Colorado: Geological Society of North America.

Rovey II, C.W., and D.S. Cherkauer. 1995. Scale dependency of hydraulic conductivity measurements. Ground Water 33, no. 5: 769-780.

Shaw, R.D., and E.E. Prepas. 1990. Groundwater-lake interactions: I. Accuracy of seepage meter estimates of lake seepage. Journal of Hydrology 119, 105-120.

Sillanpäa, M. 1956. Studies on the hydraulic conductivity of soils and its measurement. Acta Agr. Fenn. 87, 1-109.

Sophocleous, M., A. Koussis, J.L. Martin, and S.P. Perkins. 1995. Evaluation of simplified stream-aquifer depletion models for water rights administration. Ground Water 33, no. 4: 579-588.

Sperry, J.M., and J.J. Peirce. 1995. A model for estimating the hydraulic conductivity of granular material based on grain shape, grain size, and porosity. Ground Water 33, no, 6: 892-898.

Springer, A.E., W.D. Petroutson, and B.A. Semmens. 1999. Spatial and temporal variability of hydraulic conductivity in active reattachment bars of the Colorado River, Grand Canyon. Ground Water 37 , no. 3: 338-344.

Taylor, K., S. Wheatcraft, J. Hess, J. Hayworth, and F. Molz. 1990. Evaluation of methods of determining the vertical distribution of hydraulic conductivity. Ground Water 28, no. 1: 88-98.

Todd, D.K. 1980. Groundwater Hydrology. New York: John Wiley \& Sons.

Vukovic, M., and A. Soro. 1992. Determination of Hydraulic Conductivity of Porous Media from Grain-Size Composition. Littleton, Colorado: Water Resources Publications.

Walker, R.G., and D.J. Cant. 1984. Sandy fluvial systems. In Facies Models, 2nd ed., ed. R.G. Walker, 71-89. Geoscience Canada, Reprint Series 1. Toronto, Ontario: Geological Association of Canada.
Weight, W.D., and G.P. Wittman. 1999. Oscillatory slug-test data sets: A comparison of two methods. Ground Water 37, no. 6: 827-835.

Welch, S.J., D.R. Lee, and R.W.D. Killey. 1989. A comparison of methods for estimating groundwater recharge from a lake. In Proceedings of the FOCUS Conference on Eastern Regional Ground Water Issues, October 17-19, Kitchener, Ontario, Canada, 25-39. Westerville, Ohio: National Water Well Association,

Winter, T.C., J.W. LaBaugh, and D.O. Rosenberry. 1988. The design and use of a hydraulic potentiomanometer for direct measurement of differences in hydraulic head between groundwater and surface water. Limnology and Oceanography 33, no. 5: 1209-1214.

Wolf, S.H., M.A. Celia, and K.M. Hess. 1991a. Evaluation of hydraulic conductivities calculated from multiport-permeameter measurements. Ground Water 29, no. 4: 516-525.

Wolf, S.H., J.C. LaChance, and L.J. Wolf. 199lb. Techniques for monitoring flux and transport between ground water and surface water systems. In Proceedings of the Fifth National Outdoor Action Conference on Aquifer Restoration, Ground Water Monitoring, and Geophysical Methods, May 13-16, Las Vegas, Nevada, 179-192. Westerville, Ohio: National Ground Water Association.

Woessner, W.W. 2000. Stream and fluvial plain ground water interactions: Rescaling hydrogeologic thought. Ground Water 38, no. 3: 423-429.

Woodward, D. 2000. Written communication, June 26, Central Platte Natural Resources District, Grand Island, Nebraska.

Yager, R.M. 1993. Estimation of hydraulic conductivity of a riverbed and aquifer system on the Susquehanna River in Broome County, New York. U.S. Geological Survey Water-Supply Paper 2387.

Yu Z., and F.W. Schwartz. 1999. Automated calibration applied to watershed-scale flow simulations. Hydrological Processes 13, no. 2: 191-209.

Zlotnik, V. 1994. Interpretation of slug and packer tests in anisotropic aquifers. Ground Water 32, no. 5: 761-766.

Zlotnik, V., and H. Huang, 1999. Effect of shallow penetration and streambed sediments on aquifer response to stream stage fluctuations (analytical model). Ground Water 37, no. 4: 599-605.

Zlotnik, V., and V.L. McGuire. 1998a. Multi-level slug tests in highly permeable formations: 1. Modification of the Springer-Gelhar (SG) model. Journal of Hydrology 204, 271-282.

Zlotnik, V., and V.L. McGuire. 1998b. Multi-level slug tests in highly permeable formations: 2 . Hydraulic conductivity identification, method verification, and field applications. Journal of Hydrology 204, 283296. 